\title{
Cardiovascular and inflammatory effects of intratracheally instilled ambient dust from Augsburg, Germany, in spontaneously hypertensive rats (SHRs)
}

Swapna Upadhyay ${ }^{1}$, Koustav Ganguly' ${ }^{1}$ Tobias Stoeger ${ }^{1}$, Manuela Semmler-Bhenke', Shinji Takenaka', Wolfgang G Kreyling ${ }^{1,2}$, Mike Pitz ${ }^{3}$, Peter Reitmeir ${ }^{4}$, Annette Peters ${ }^{3}$, Oliver Eickelberg ${ }^{1}$, H Erich Wichmann ${ }^{2,3}$, Holger Schulz ${ }^{1,2^{*}}$

\begin{abstract}
Rationale: Several epidemiological studies associated exposure to increased levels of particulate matter in Augsburg, Germany with cardiovascular mortality and morbidity. To elucidate the mechanisms of cardiovascular impairments we investigated the cardiopulmonary responses in spontaneously hypertensive rats (SHR), a model for human cardiovascular diseases, following intratracheal instillation of dust samples from Augsburg.

Methods: $250 \mu \mathrm{g}, 500 \mu \mathrm{g}$ and $1000 \mu \mathrm{g}$ of fine ambient particles (aerodynamic diameter $<2.5 \mu \mathrm{m}, \mathrm{PM}_{2.5}-\mathrm{AB}$ ) collected from an urban background site in Augsburg during September and October $2006\left(\mathrm{PM}_{2.5} 18.2 \mathrm{\mu g} / \mathrm{m}^{3}\right.$, 10,802 particles $/ \mathrm{cm}^{3}$ ) were instilled in 12 months old SHRs to assess the inflammatory response in bronchoalveolar lavage fluid (BALF), blood, lung and heart tissues 1 and 3 days post instillation. Radio-telemetric analysis was performed to investigate the cardiovascular responses following instillation of particles at the highest dosage based on the inflammatory response observed.

Results: Exposure to $1000 \mu \mathrm{g}$ of $\mathrm{PM}_{2.5}-\mathrm{AB}$ was associated with a delayed increase in delta mean blood pressure $(\triangle \mathrm{mBP})$ during $2^{\text {nd }}-4^{\text {th }}$ day after instillation $(10.0 \pm 4.0 \mathrm{vs}$. $-3.9 \pm 2.6 \mathrm{mmHg})$ and reduced heart rate $(H R)$ on the $3^{\text {rd }}$ day post instillation $(325.1 \pm 8.8$ vs. $348.9 \pm 12.5 \mathrm{bpm})$. BALF cell differential and inflammatory markers (osteopontin, interleukin-6, C-reactive protein, and macrophage inflammatory protein-2) from pulmonary and systemic level were significantly induced, mostly in a dose-dependent way. Protein analysis of various markers indicate that $\mathrm{PM}_{2.5}-\mathrm{AB}$ instillation results in an activation of endothelin system (endothelin 1), renin-angiotensin system (angiotensin converting enzyme) and also coagulation system (tissue factor, plasminogen activator inhibitor-1) in pulmonary and cardiac tissues during the same time period when alternation in $\triangle \mathrm{mBP}$ and HR have been detected.

Conclusions: Our data suggests that high concentrations of $\mathrm{PM}_{2.5}-\mathrm{AB}$ exposure triggers low grade $\mathrm{PM}$ mediated inflammatory effects in the lungs but disturbs vascular homeostasis in pulmonary tissues and on a systemic level by affecting the renin angiotensin system, the endothelin system and the coagulation cascade. These findings are indicative for promotion of endothelial dysfunction, atherosclerotic lesions, and thrombogeneis and, thus, provide plausible evidence that susceptible-predisposed individuals may develop acute cardiac events like myocardial infarction when repeatedly exposed to high pollution episodes as observed in epidemiological studies in Augsburg, Germany.
\end{abstract}

\footnotetext{
* Correspondence: schulz@helmholtz-muenchen.de

${ }^{1}$ Comprehensive Pneumology Center, Institute of Lung Biology and Disease, Helmholtz Zentrum München, German Research Center for Environmental Health, Ingolstaedter Landstrasse 1, D85764, Neuherberg/Munich, Germany Full list of author information is available at the end of the article
} 


\section{Introduction}

Epidemiological studies have linked ambient particulate matter (PM) levels to an increased incidence of adverse cardiovascular events. The World Health Organization [1] reported that over 800,000 premature deaths worldwide per year can be attributed to PM air pollution [1]. Numerous epidemiological studies have linked short-term and long-term PM exposures to increased mortality [2-5]. An analysis by Pope et al. [6] indicated that with every $10 \mu \mathrm{g} / \mathrm{m}^{3}$ increase in atmospheric $\mathrm{PM}_{2.5}$, cardiopulmonary mortality increased by $6 \%$. For a similar increase in $\mathrm{PM}_{2.5}$, it has been shown that there is a $2.1 \%$ increase in the number of deaths related to ischemic heart disease [7]. Short-term increases in PM exposure elevate the incidence of ischemic cardiac disease and congestive cardiac failure with specific pathophysiological end points like myocardial infarction, arrhythmias, reduced heart-rate variability (HRV), and elevated heart rate (HR) in adults [5,8-12]. Inhalation of PM may cause pulmonary inflammation characterized by neutrophil and macrophage activation [13-16] associated with a subsequent systemic inflammatory response and the disturbance of endothelial function and activation of the blood coagulability [15-19]. Repeatedly, PM was associated with an increase in serum levels of C-reactive protein, the classical acute phase reactant indicative for a systemic inflammatory response which is considered to be a risk factor for cardiovascular diseases $[7,15,20,21]$. However, the underlying pathophysiological mechanisms of airborne $\mathrm{PM}_{2.5}$ mediated cardiopulmonary mortality and morbidity are complex and remain to a large extent unexplored.

Several epidemiological studies on PM associated cardiovascular effects were conducted in Augsburg, a medium sized city located in Southern Germany with about 250,000 inhabitants and no heavy industry, by using the 'Cooperative Health Research in the Region of Augsburg (KORA)' platform. In January 1985, an air pollution episode occurred throughout Central Europe [22] resulting in an increase of hospital admissions for cardiovascular diseases, such as acute coronary syndromes and arrhythmias [23]. The first MONICA survey (MONItoring of trends and determinants in Cardiovascular disease) was carried out in Augsburg during that winter period which included the days of the pollution episode [24]. Peters et al [20] reported that PM in the Augsburg atmosphere may have induced systemic inflammation as suggested by increased C-reactive protein levels and increased plasma viscosity [17]. In several epidemiological studies, exposure to Augsburg dust was associated with an increase in HR [9], arterial BP and an altered autonomic control [25] as well as the increased incidences of myocardial infarction among susceptible per- sons [[5,26]; Figure 1). Since 1985 exposure to airborne PM has changed in Augsburg mainly due to modified emissions of combustion sources. It continues to pose threat to the population in Augsburg for various alignments mainly cardiopulmonary disorders.

Therefore investigations on the causative pathomechanism for cardiovascular diseases due to PM exposure will help immensely in understanding the molecular phenomenon and support preventive, such as creation of low emission zones, or curative strategies. To address the potential underlying pathomechanism for PM associated cardiovascular diseases, spontaneously hypertensive rats (SHRs; 12 months), a well established animal model of human cardiovascular disease were exposed to $\mathrm{PM}_{2.5}-\mathrm{AB}$ collected during September and October 2006 by intratracheal (i.t.) instillation and assessed for cardiopulmonary responses, its temporal assignment, and its potential molecular basis. We hypothesized that either by direct particle-cell interaction or by inflammatory responses in the lungs and/or on the systemic level exposure to $\mathrm{PM}_{2.5}-\mathrm{AB}$ induces markers of endothelial dysfunction which promotes a pro-coagulatory state and may induce areteriosclerotic lesions. Exposure also affects the vasoregulatory homeostasis by affecting the endothelin and the renin-angiotensin system (RAS) resulting in an increased arterial BP which ultimately contribute to an increased afterload and oxygen demand of the heart. We expect effects of a single exposure to be small and, taken as a unique event, to be clinically of minor importance in subjects with sufficient cardiovascular reserves. However, repeated exposures over several years as given in the environmental setting of Augsburg is supposed to promote cardiovascular disorders and eventually contribute to trigger fatal cardiac events in susceptible subjects such as myocardial infarction documented in the epidemiological studies. In the present study we focused on the acute response detectable within 5 days after a single instillation of $\mathrm{PM}_{2.5}-\mathrm{AB}$ and analysed a panel of protein markers assessing vasoregulatory pathways (Endothelin1, RAS) and markers indicative for coagulation and atherosclerosis (PAI-1;TF; VCAM-1) and angiogenesis (VEGF). Our findings provide evidence for plausible molecular mechanisms underlying low grade $\mathrm{PM}_{2.5}-\mathrm{AB}$ mediated inflammatory effects and alterations of the vascular homeostasis. We could show that a single exposure of SHRs to $\mathrm{PM}_{2.5}-\mathrm{AB}$ induces a slight inflammatory response in pulmonary and systemic tissues, including activation of the endothelial and vasoregulatory system and promotion of a pro-coagulatory state. This may contribute to the development of cardiovascular disorders and to cardiac events in susceptible persons as observed in epidemiological studies in Augsburg (Figure 1). 


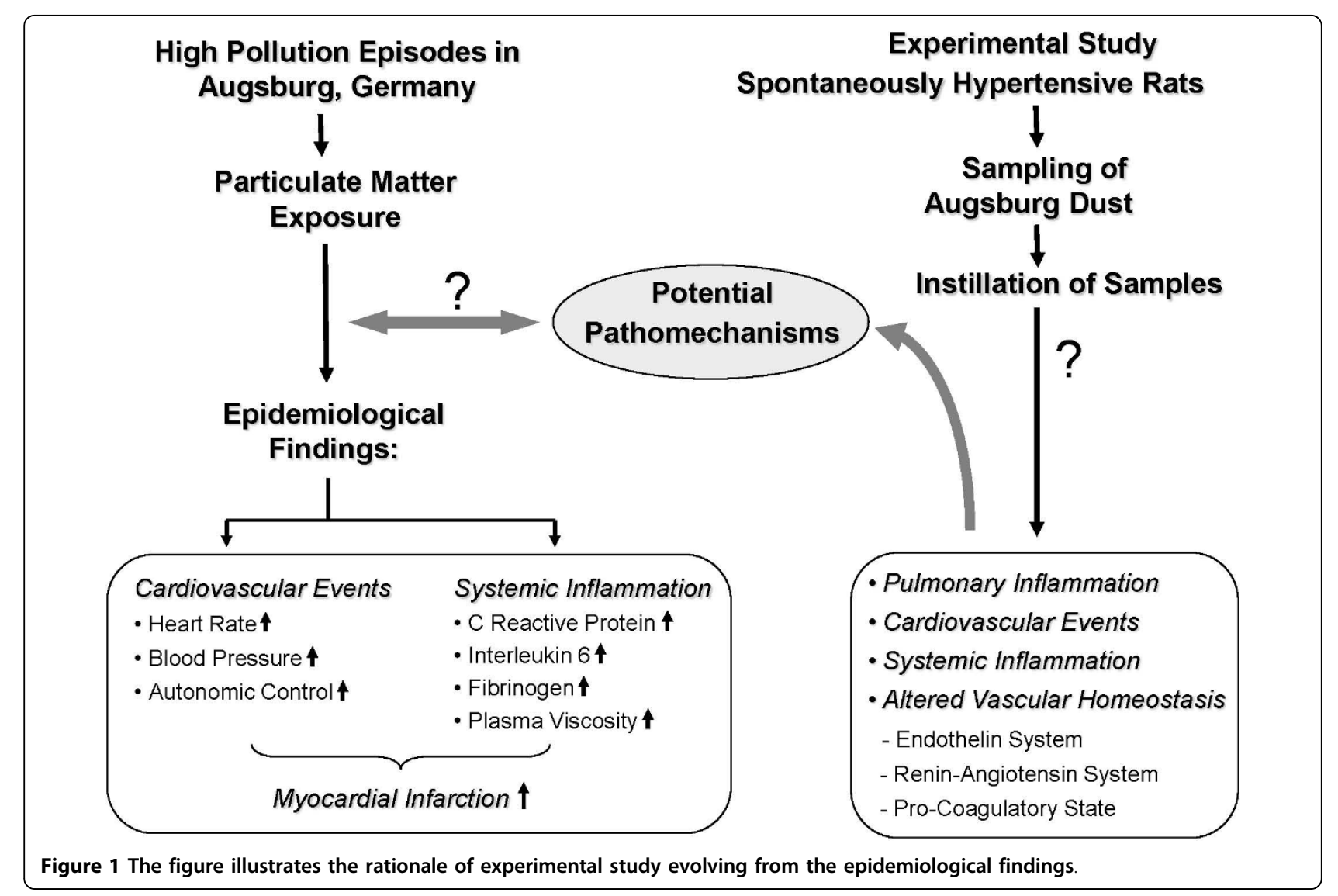

\section{Results}

SHR were intra tracheally (i.t.) instilled with ambient $\mathrm{PM}_{2.5}$ collected from Augsburg, Germany, and were assessed for cardiophysiological response using radio telemetry on 5 consecutive days post exposure. To assess inflammatory responses in the lung and on a systemic level standard bronchoalveolar lavage fluid (BALF), blood samples, and tissue samples from heart and lung were obtained on day 1 and 3 after instillation. Histopathological studies were carried out in lung and heart. Protein concentrations of various inflammatory markers were measured in BALF, lung and heart. Focused analysis of biomarkers (at protein level) associated with hypertension (angiotensin converting enzyme: ACE), endothelial activation (endothelin-1: ET-1), coagulation factors (tissue factor: TF; plasminogen activator inhibitor-1: PAI-1), atherosclerosis (vascular cell adhesion molecule 1 : VACM-1) and angiogenesis (vascular endothelial growth factor: VEGF) was performed from the lung and heart. Sham (water/vehicle) instilled animals served as control.

\section{Cardiovascular response assessed by radio telemetry}

To address the $\mathrm{PM}_{2.5}-\mathrm{AB}$ induced cardiovascular response a well established animal model (spontaneously hypertensive rats, SHRs) of human cardiovascular disease has been used in the present study. All animals (SHRs; 12 months) showed clear signs of cardiovascular disease at the time of investigation. Mean blood pressure (mBP) of unexposed rats ranged between 169 and $208 \mathrm{mmHg}$ and mean heart weight between 1463 and $2112 \mathrm{mg}$, thus, being substantially elevated compared to non-hypertensive WKY rats $[27,28]$. Despite being kept under identical housing conditions the extent of hypertension and its effects on secondary organs varied between animals. The animals were randomly assigned to the control or exposure group, respectively.

Figure 2 summarizes effects on the cardiovascular system following instillation of $1000 \mu \mathrm{g}$ of $\mathrm{PM}_{2.5}-\mathrm{AB}$. After $\mathrm{PM}_{2.5}-\mathrm{AB}$ exposure no significant differences between control and exposed animals were detectable for absolute values of $\mathrm{mBP}$ (Figure 2a). However, the interpretation of $\mathrm{mBP}$ data based on absolute values is limited in this case because baseline data were $9 \%$ lower in exposed than in control animals (exposed: $181.1 \pm 4.8 \mathrm{mmHg}$ versus control: $197.0 \pm 2.8 \mathrm{mmHg}, \mathrm{p}<0.02)$. Differences in $\mathrm{mBP}$ were due to a moderate changes in systolic (exposure: $199.6 \pm 4.0 \mathrm{mmHg}$ versus control: $226 \pm 2.5 \mathrm{mmHg}$ ) and diastolic (exposure: $162.5 \pm 6.1 \mathrm{mmHg}$ versus control/ $168 \pm 3.1 \mathrm{mmHg})$ BP. Therefore, individual mBP differences $(\triangle \mathrm{mBP})$ were calculated from post exposure values 

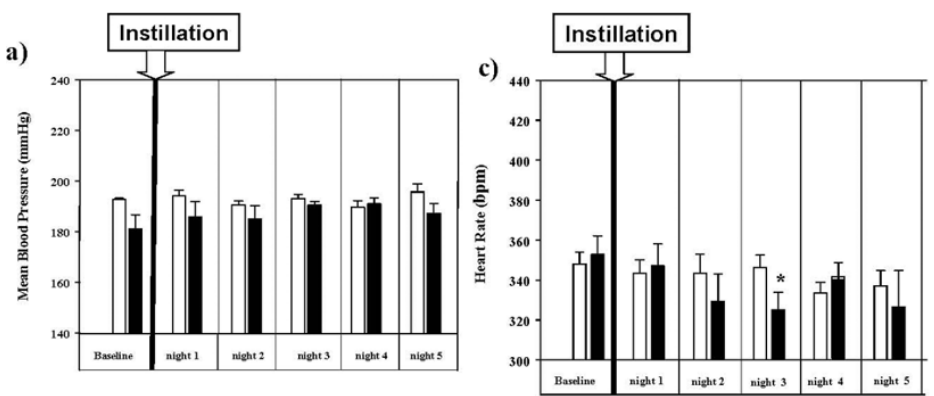

b)

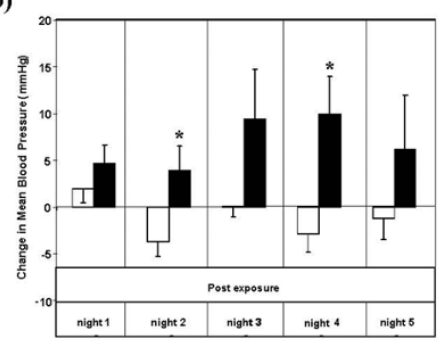

d)
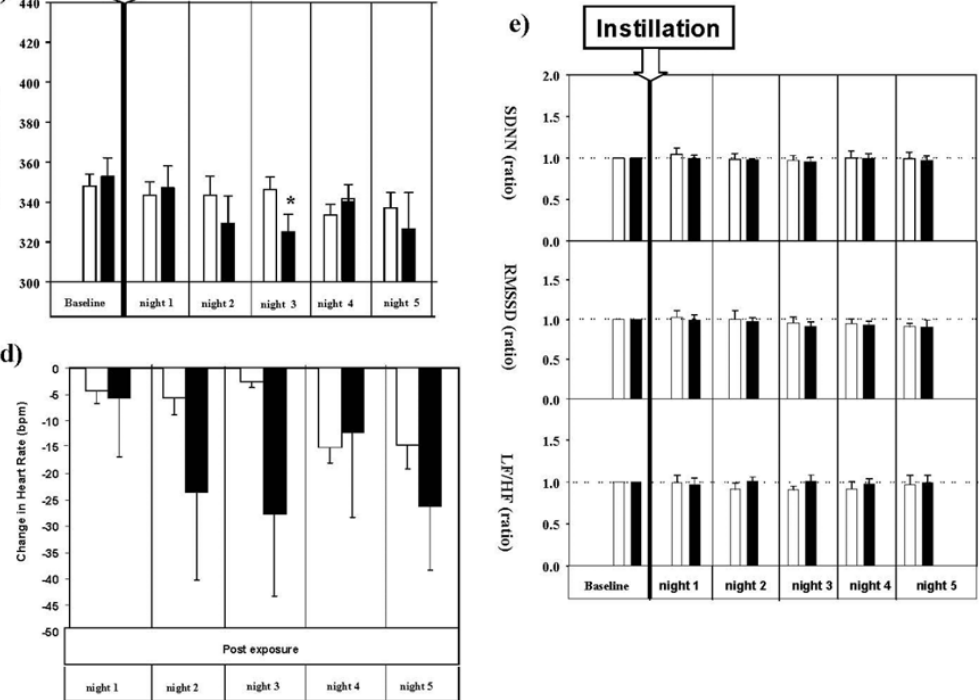

*indicates significant difference of $(p<0.04: B P ; p<0.03$ : HR) between sham (white) and exposed (black) SHRs.

Figure 2 Mean blood pressure (mBP, 2a); Changes in individual mean blood pressure (delta mBP, 2b); Heart rate (HR, 2c); Changes in individual heart rate (delta HR, 2d); and Changes in time domain and frequency domain measures of heart rate variability (HRV, 2e) in sham (control) or Augsburg particulate matter ( $\mathbf{P M}_{2.5}-\mathbf{A B}$, exposed) instilled SHRs. The vertical bars exhibit arithmetic mean values (mean \pm SE) of sham (white; $n=5$ ) and exposed (black; $n=5$ ) groups. The summary statistics for the analysis of repeated measurements revealed that delta $\mathrm{mBP}$ differences between groups were significant on day 2 and 4 post exposure $(p<0.04)$. Delta mBP declined and reached almost baseline values on day 5. Absolute HR values responded with a lag of 1 day to $\mathrm{PM}_{25}-\mathrm{AB}$ exposure and were significantly lower in the exposure group by $6 \%(325.1 \pm 8.8 \mathrm{bpm}$ vs $348.9 \pm 12.5 \mathrm{bpm}, \mathrm{p}<0.03)$ on the $3^{\text {rd }}$ day after instillation. The summary statistics for the analysis of repeated measurements revealed that neither the area under the curve nor differences in HR values reached the level of statistical significance. In Figure 2e each bar represents a combined mean value of: 12 -minutes segments/12-h dark period/rat) from 5 rats. SDNN: standard deviation of normal to normal (NN) intervals. RMSSD: square root of the mean of squared differences between adjacent NN intervals. LF/HF: ratio of the absolute powers in the low-frequency (LF: $0.20 \mathrm{~Hz}$ to $0.75 \mathrm{~Hz}$ ) and high-frequency bands HF: $0.75 \mathrm{~Hz}$ to $2.5 \mathrm{~Hz}$ ). ${ }^{*}$ indicates significant difference of ( $p<0.04$ : BP; $p<0.03$ : HR) between exposed (black) and sham (white) SHRs.

related to the respective baseline (Figure $2 \mathrm{~b}$ ). The summary statistics for the analysis of repeated measurements (AUC statistics) revealed that differences in control animals varied randomly between $-3.8 \pm 1.5 \mathrm{mmHg}$ (day 2 post exposure) and $+2.0 \pm 1.6 \mathrm{mmHg}$ (day 1 post exposure) while those observed in exposed animals increased with a lag of 1 day and peaked on post exposure day 4 $(+10.0 \pm 4.0 \mathrm{mmHg}, \mathrm{p}<0.05)$. Delta mBP differences between groups were significant on day 2 and 4 post exposure ( $\mathrm{p}<0.04$, paired t-test). Equivalent changes were observed on day 3 , although statistically not significant $(\mathrm{p}<0.1$, paired $\mathrm{t}$-test). Delta $\mathrm{mBP}$ declined and reached almost baseline values on post exposure day 5 $(6.2 \pm 5.8 \mathrm{mmHg}$; not significant $)$.

Baseline measurements of HR revealed comparable values between both groups, i.e. $351.6 \pm 5.7$ and $352.8 \pm$ 9.4 in control and exposed animals, respectively (Figure 2c, not significant). Absolute HR values responded with a lag of 1 day to $\mathrm{PM}_{2.5}$ - $\mathrm{AB}$ exposure and were significantly lower in the exposure group by $6 \%(325.1 \pm 8.8$ bpm vs $348.9 \pm 12.5 \mathrm{bpm}, \mathrm{p}<0.03)$ on the $3^{\text {rd }}$ post exposure day. However, applying the same statistical approaches as used for $\mathrm{mBP}$ neither the area under the curve nor differences in HR values (Figure 2d) reached the level of statistical significance.

The standard deviation of all normal adjacent sinus intervals (SDNN), a measure of the overall heart-rate variability (HRV), the square root of the mean of squared differences between adjacent normal to normal intervals (RMSSD) and the low-frequency to high-frequency ratio (LF/HF) remained unaffected in exposed SHRs compared to their control (Figure 2e).

\section{Acute pulmonary inflammatory response}

BALF and lung: Typically for SHRs, elevated cell numbers were detected compared to healthy rats [29]. Intratracheal 
instillation of $\mathrm{PM}_{2.5}-\mathrm{AB}$ resulted in a slight increase of BALF derived inflammatory cells at day 1 post instillation (Figure 3a). Dose dependent increases in macrophages (Figure 3b), polymorphonuclear leukocytes (PMNs) (Figure $3 \mathrm{c}$ ), and lymphocytes (Figure $3 \mathrm{~d}$ ) occurred in on day 1 $(24 \mathrm{~h})$ in $500 \mu \mathrm{g}$ and $1000 \mu \mathrm{g} \mathrm{PM}_{2.5}-\mathrm{AB}$ exposed animals. The total lavagable cells, especially the $\mathrm{PM}_{2.5}-\mathrm{AB}$ associated influx of PMN and lymphocytes were largely reversed by day $3(72 \mathrm{~h})$ and reached baseline values. At the exposure dose of $250 \mu \mathrm{g}$ total lavageable cells and cell differentials did not exhibit any significant difference compared to sham.

To characterize the degree of inflammatory changes in the lung at a molecular level, we analyzed key inflammatory markers [30] at protein level (IL-6 and osteopontin;
Figures 4a-b) from BALF and lung homogenate (macrophage inflammatory protein-2/MIP-2 and tumor necrosis factor alpha/TNF- $\alpha$; Figure 4c). IL-6 was induced by 2.5 fold and 4.0 fold $(\mathrm{p}<0.05$; Figure $4 \mathrm{a})$ in the BALF on day 1 post instillation of $500 \mu \mathrm{g}$ and $1000 \mu \mathrm{g} \mathrm{PM}_{2.5}-$ $\mathrm{AB}$, respectively, compared to sham. Osteopontin concentration in BALF was significantly increased by 2.0 fold only at the highest dose $(1000 \mu \mathrm{g} ; \mathrm{p}<0.05$; Figure $4 \mathrm{~b})$ compared to sham at day 1 post instillation. Both IL- 6 and osteopontin concentrations were reversed by day 3 and reached near to baseline values.

Concentrations of MIP2 in the lung were only slightly affected (Figure 4c). Intratracheal instillation of $1000 \mu \mathrm{g}$ $\mathrm{PM}_{2.5}$ - AB significantly increased the MIP-2 (1.3 fold; $\mathrm{p}<0.05)$ concentration at the day 1 and 3 post instillation

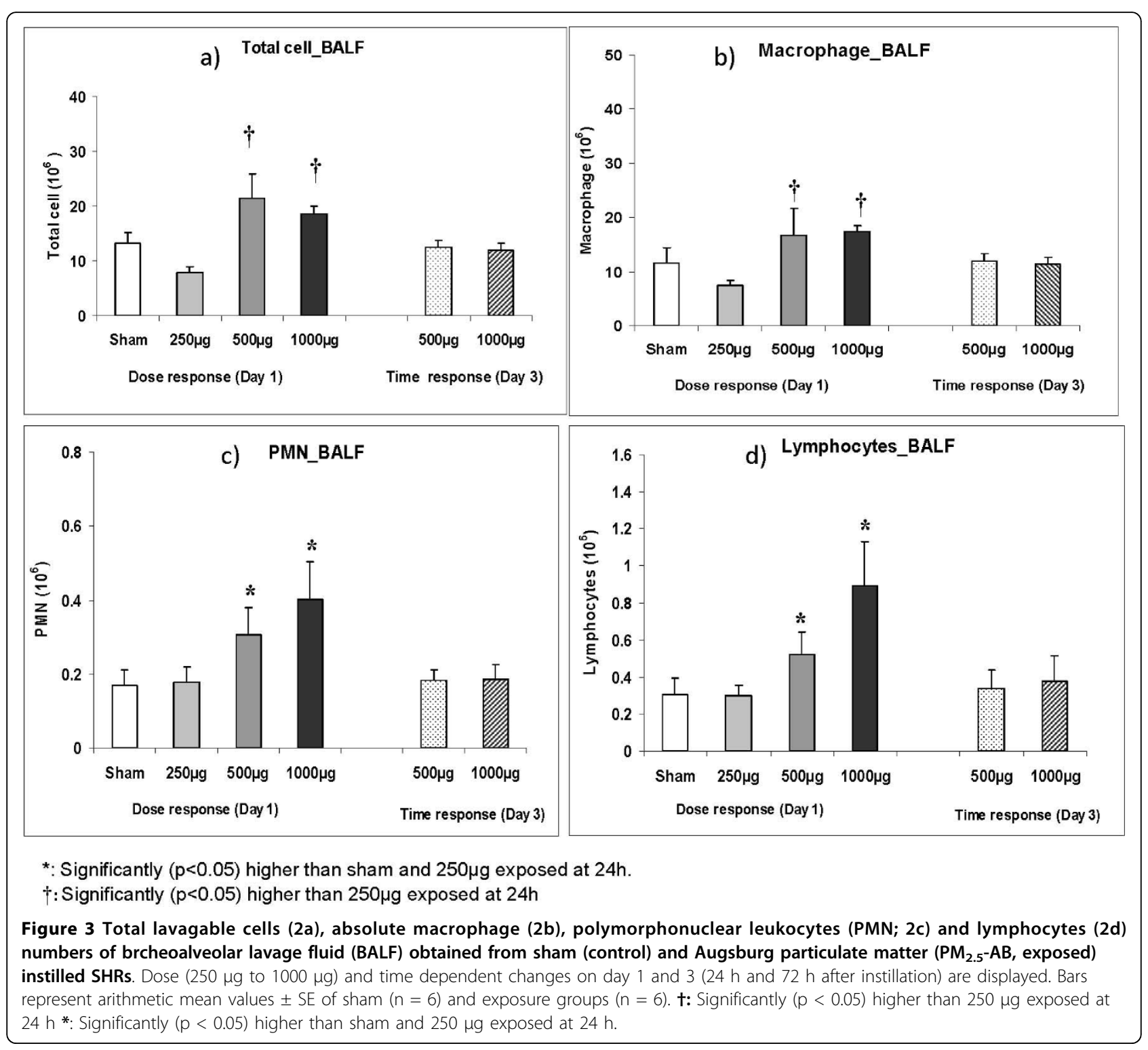


a)

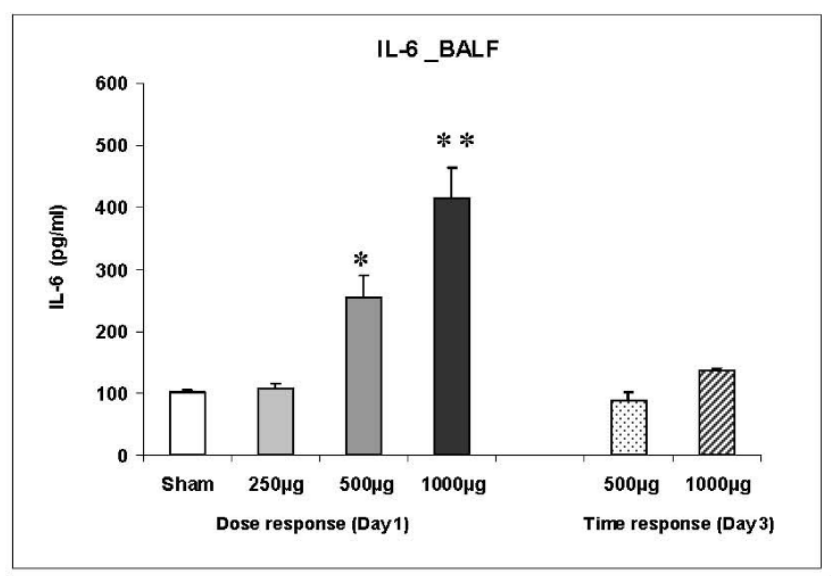

b)

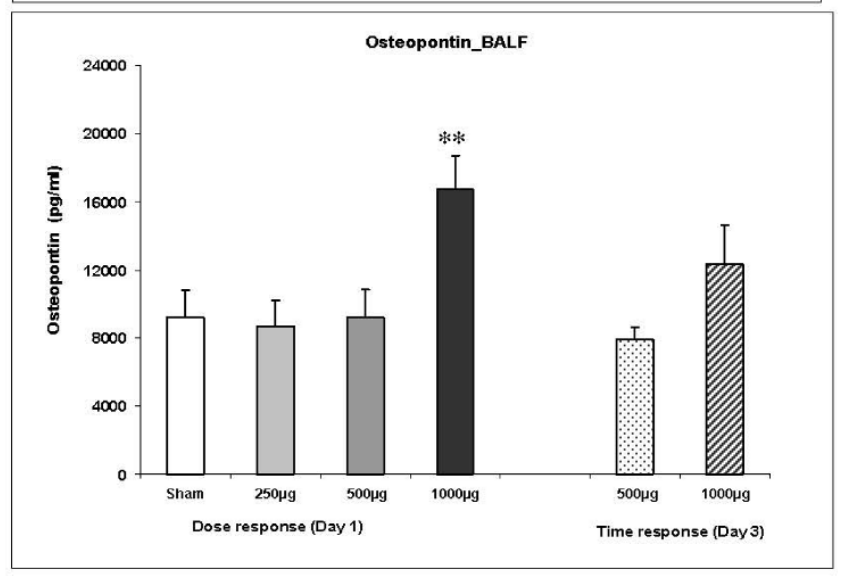

c)

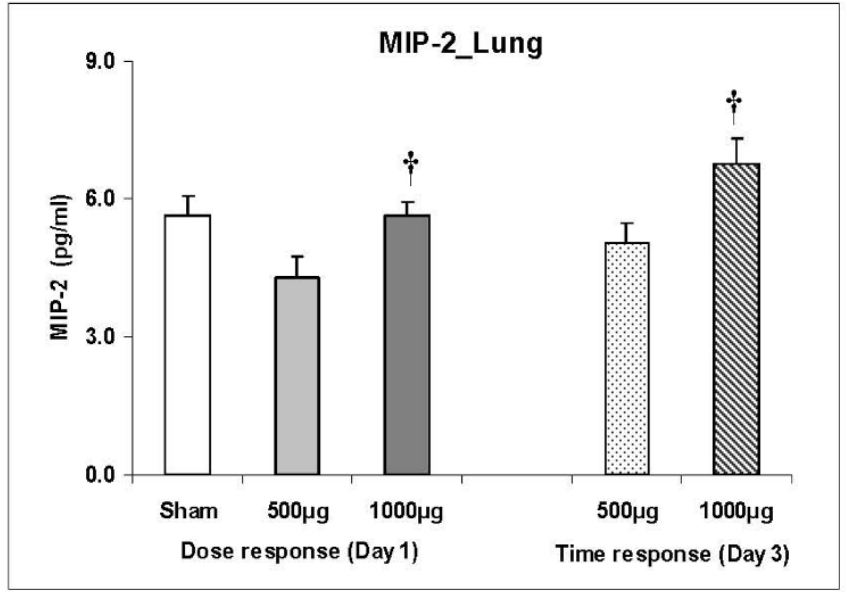

\section{*: Significantly $(p<0.05)$ higher than sham and $250 \mu \mathrm{g}$ exposed at $24 \mathrm{~h}$ $* *$ : Significantly $(p<0.05)$ higher than sham and exposed at day 1 $\uparrow:$ Significantly $(p<0.05)$ higher than $500 \mu g$ exposed at day 1 and 3}

Figure 4 Response of pulmonary inflammation markers in the bronchoalveolar lavage fluid (BALF). Concentrations of Interleukin-6 (IL-6) (3a), osteopontin (3b), and macrophage inflammatory protein-2 (MIP-2) in lung homogenate (3c) following intratracheal (i.t.) instillation of sham and Augsburg particulate matter (PM $2.5-A B$, exposed) in SHRs are shown. Bars represent arithmetic mean values $\pm S E$ of sham $(n=6)$ and exposure groups $(n=6)$. IL-6 exhibited a typical dose-time response in the BALF. Osteopontin in the BALF and MIP-2 in the lung homogenate (3c) was affected only at the highest dose $(1000 \mu \mathrm{g})$. *: Significantly $(\mathrm{p}<0.05)$ higher than sham and $250 \mu \mathrm{g}$ exposed at $24 \mathrm{~h}$ **: Significantly $(p<0.05)$ higher than sham and exposed at day 1 . + : Significantly $(p<0.05)$ higher than $500 \mu$ g exposed at day 1 and 3. 
compared to their corresponding $500 \mu \mathrm{g}$ exposed group but was not significantly affected compared to sham. TNF- $\alpha$ expression was not significantly altered in any of the doses (data not shown).

\section{Pulmonary histopathology}

Pulmonary histopathological analysis by light microscopy examination of representative lung sections revealed moderate accumulation of mononuclear cells in the lungs due to the advanced cardiovascular state of the animals [29,31]. A slight inflammatory response with some PMN influx and particle-laden macrophages, were detectable at high doses of $\mathrm{PM}_{2.5} \mathrm{AB}$ (Figure $5 \mathrm{i}$ and $5 \mathrm{j}$ ). There were no signs of $\mathrm{PM}_{2.5}-\mathrm{AB}$ induced lung injury, even at the highest dose applied.

\section{Systemic inflammatory response}

Acute phase response To assess whether $\mathrm{PM}_{2.5}-\mathrm{AB}$ instillation induces an inflammatory response at the systemic level, serum levels of the "acute phase reactant", C-reactive protein (CRP) was determined. A clearly delayed increase of CRP was observed in a dose-dependent manner (Figure 6a) with a 4.4 fold induction of CRP on day 3 following instillation of $1000 \mu \mathrm{g} \mathrm{PM}_{2.5}-\mathrm{AB}(\mathrm{p}<0.05)$ and a 2.4 fold induction at $500 \mu \mathrm{g}(\mathrm{p}<0.05)$. At day 1 CRP was not affected after $500 \mu \mathrm{g} \mathrm{PM}_{2.5}$ - $\mathrm{AB}$ albeit slightly but significantly (1.6 fold; $\mathrm{p}<0.05)$ increased after instillation of 1000 $\mu \mathrm{g}$ compared to sham.

Haematology The complete blood cell count, i.e. total red (haematocrit) and white blood cells, (platelets, neutrophils and lymphocytes) was assessed on $1^{\text {st }}$ and $3^{\text {rd }}$ day after instillation and revealed no alterations between sham and exposed animals.

Cardiac tissue A delayed gradual induction of osteopontin and MIP-2 was observed in cardiac tissue (Figures 6b and 6c). Osteopontin was significantly induced by 2.4 fold only at the highest dose $(1000 \mu \mathrm{g}$; Figure $6 \mathrm{~b} ; \mathrm{p}<0.05)$ on day 3 post instillation. MIP-2 reflected a similar response as it is observed in the pulmonary tissue. At $1000 \mu \mathrm{g} \mathrm{PM}_{2.5}$ - AB MIP-2 was significantly induced by 1.5 fold at day 1 and by 2 fold ( $\mathrm{p}<$ 0.05 ; Figure $6 \mathrm{c}$ ) at day 3 compared to sham. TNF- $\alpha$ was not affected (data not shown).

\section{$\mathrm{PM}_{2.5}$ mediated effects on vascular homeostasis Pulmonary protein analysis}

ACE, ET-1, TF, PAI-1, VACM-1 and VEGF protein concentrations were assessed from lung tissues of $\mathrm{PM}_{2.5}-\mathrm{AB}$ exposed SHRs on day 1 and day 3 post instillation (Figures 7a-f; see Table 1). ET1, and TF were significantly reduced by about 35\% (1.5 fold repression, $\mathrm{p}<0.05)$ at both $\mathrm{PM}_{2.5}-\mathrm{AB}$ concentrations and did not recover over the time period of investigation. ACE was affected only at the highest concentration $(1000 \mu \mathrm{g})$. ACE levels decreased to about $75 \%$ of its activity (1.3 fold repression, $\mathrm{p}<0.05)$ at day 1 and exhibited an even stronger decrease to about 35\% ( 3 fold repression, $\mathrm{p}<0.05$ ) on day 3. PAI-1 (1.5 fold) and VCAM-1 (1.3 fold) were significantly $(\mathrm{p}<0.05)$ increased following instillation of $500 \mu \mathrm{g}$ of $\mathrm{PM}_{2.5}-\mathrm{AB}$ on day 1 , while VEGF was significantly induced $(1.5$ fold; $\mathrm{p}<0.05)$ only at the highest dose $(1000 \mu \mathrm{g})$ compared to sham. For PAI-1 an initial increase was not detected at the highest concentration but on day 3 a strong reduction at both 500 and $1000 \mu \mathrm{g}$ of $\mathrm{PM}_{2.5}-\mathrm{AB}$ to $40 \%$ and $15 \%$, respectively (2.4 and 6.5 fold repression, respectively, $\mathrm{p}<0.05$ ) was observed.

\section{Cardiac protein analysis}

The markers assessed in lung were also measured in the heart tissue at day 1 and 3 after instillation (Figures 7a-f; see Table 1). ACE was induced by 1.4 fold at $1000 \mu \mathrm{g}$ $(\mathrm{p}<0.05)$ on day 1 and 3 post instillation compared to sham. Similarly, ET-1 was significantly induced by 1.5 fold ( $\mathrm{p}<0.05$ ) on day 1 and 3 following instillation of 1000 and $500 \mu \mathrm{g}$ of $\mathrm{PM}_{2.5}$ compared to sham. At $1000 \mu \mathrm{g}$ of $\mathrm{PM}_{2.5}-\mathrm{AB}$ on day 3 post instillation ET-1 was induced by 2.1 fold $(\mathrm{p}<0.05)$. On day 3 post instillation almost 2 fold ( $\mathrm{p}<0.05$ ) elevated concentrations of PAI-1 and TF were detected. VCAM-1 was induced by 1.6 ( $\mathrm{p}<0.05)$ fold at $1000 \mu \mathrm{g}$ of $\mathrm{PM}_{2.5}$-AB compared to sham. VEGF was not affected in the heart tissue. As evident, in contrast to the pulmonary response most of these markers exhibit a delayed induction in the cardiac tissue with time (day 3 post instillation) matching the cardiophysiological alterations.

\section{Cardiac histopathology}

No signs of inflammation or cardiomyopathy following instillation of ambient particle could be detected by histological analysis (data not shown).

\section{Discussion}

Epidemiological studies have identified exposure to elevated concentrations of ambient PM as a risk factor for the exacerbation of ischemic heart disease and congestive heart failure $[32,33]$. Epidemiological findings in the region of Augsburg, Germany, showed that elevated levels of PM are associated with an increased incidence of myocardial infarction $[5,26]$ and also with increased levels of markers indicative for early systemic effects, like CRP and IL-6, or with plasma viscosity $[9,17,20,26,34]$. Therefore, it becomes apparent that air pollution events in Augsburg influence cardiopulmonary physiology. Hence, the authors propose that a PM induced low grade, sustained systemic inflammation and modulation of the autonomic function of the heart and the vasomotor activity are potential underlying mechanisms for fatal cardiac event as also suggested by several other epidemiological studies $[5,9,10,17,25,26]$. As the selections of epidemiological cohorts in most cases are random, the 


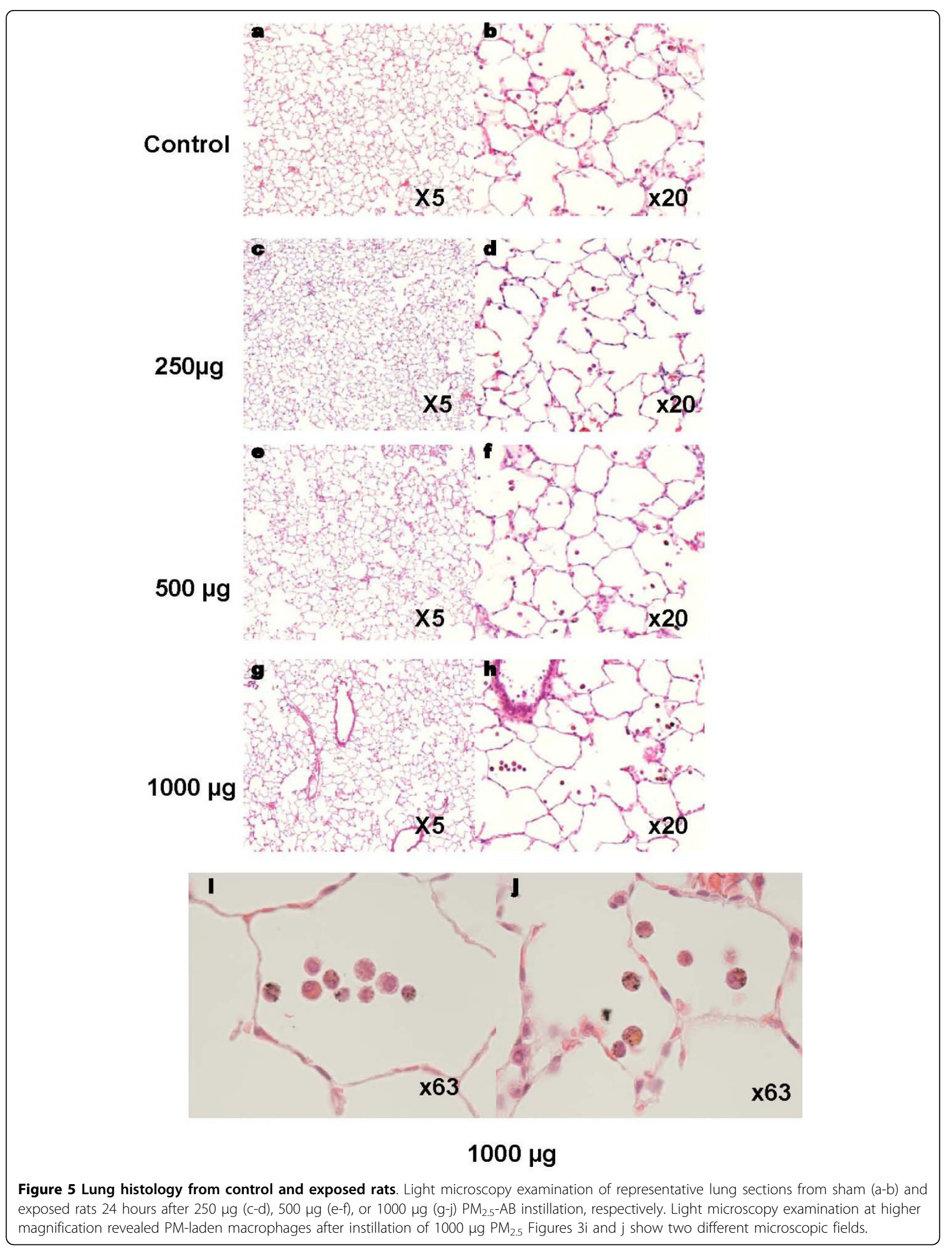


a)

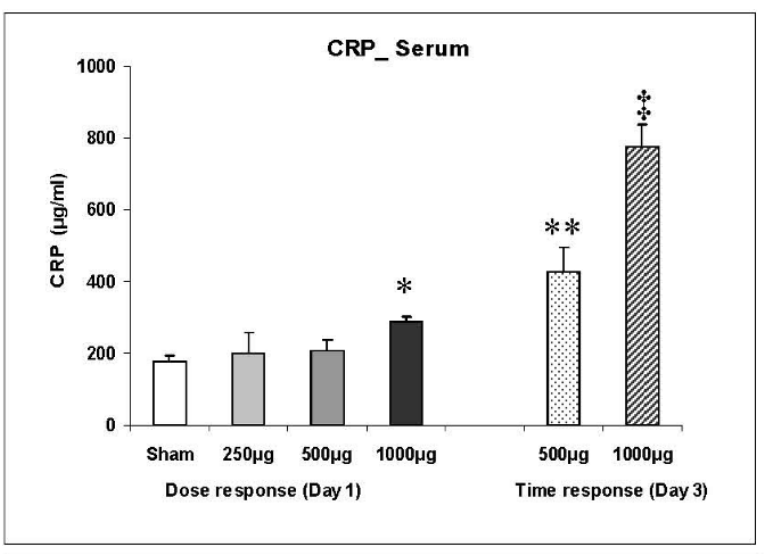

b)

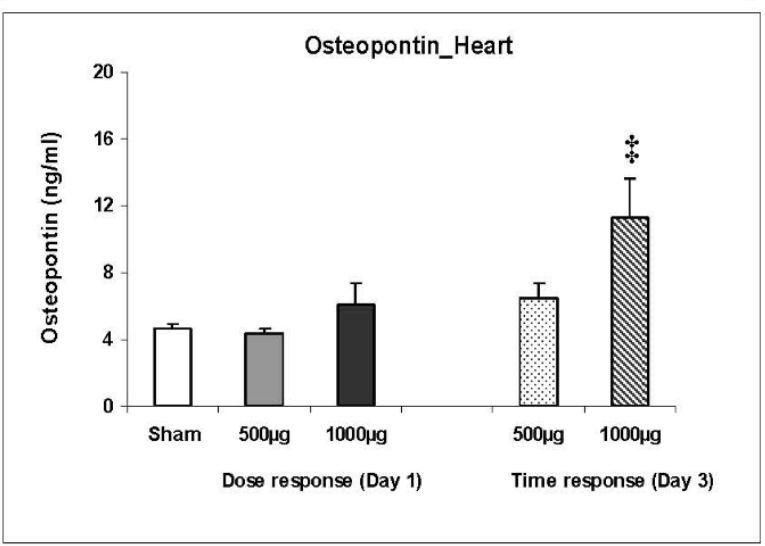

c)

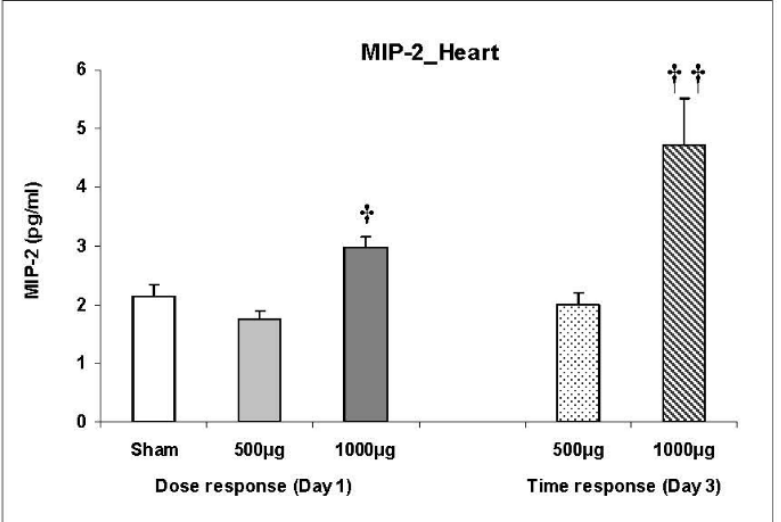

*: Significantly $(\mathrm{p}<0.05)$ higher than sham, $250 \mu \mathrm{g}$ and $500 \mu \mathrm{g}$ exposed at day 1

$* *$ : Significantly $(p<0.05)$ higher than sham and exposed at day 1.

†: Significantly $(p<0.05)$ higher than sham and exposed at day 1 and 3.

$\dagger$ : Significantly $(\mathrm{p}<0.05)$ higher than $500 \mu \mathrm{g}$ exposed at day 1 .

$\dagger \uparrow:$ Significantly $(p<0.05)$ higher than sham and $500 \mu \mathrm{g}$ exposed at both day 1 and 3 .

Figure 6 Response of the systemic Inflammatory marker C-reactive protein (CRP) in the serum (3a), and of osteopontin (3b) and macrophage inflammatory protein 2/MIP-2 (3c) in the heart following intratracheal instillation of sham and Augsburg particulate matter $\left(\mathbf{P M}_{2.5}-\mathbf{A B}\right.$, exposed) in spontaneously hypertensive rats (SHRs). Bars represent arithmetic mean values $\pm S E$ of sham $(n=6)$ and exposure groups $(n=6)$. A delayed increase of CRP was observed in a dose-dependent manner whereas osteopontin and MIP2 were induced only at the highest dose. *: Significantly $(p<0.05)$ higher than sham, $250 \mu \mathrm{g}$ and $500 \mu \mathrm{g}$ exposed at day 1. **: Significantly $(p<0.05)$ higher than sham and exposed at day 1. ¥: Significantly $(p<0.05)$ higher than sham and exposed at day 1 and 3. †: Significantly $(p<0.05)$ higher than $500 \mu \mathrm{g}$ exposed at day 1. $\mathrm{t+}$ : Significantly $(\mathrm{p}<0.05)$ higher than sham and $500 \mu \mathrm{g}$ exposed at both day 1 and 3. 
a)

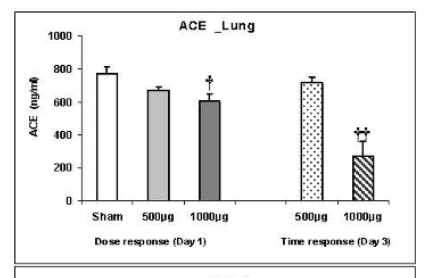

b)

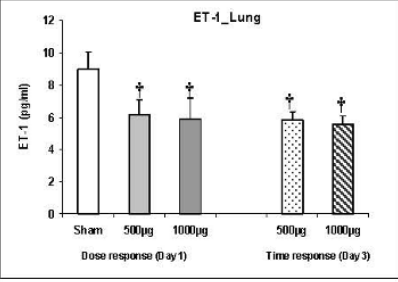

c)

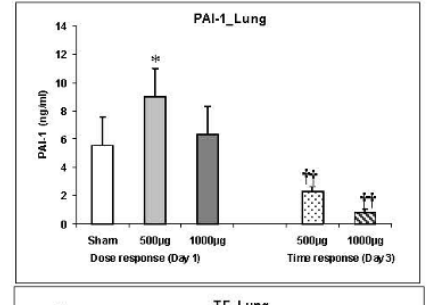

d)

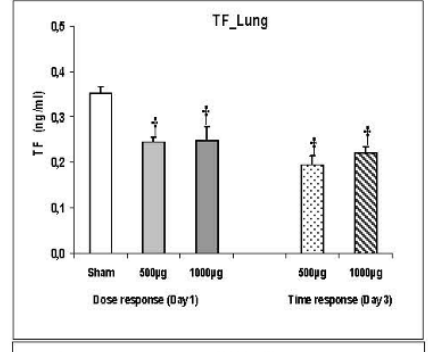

e)

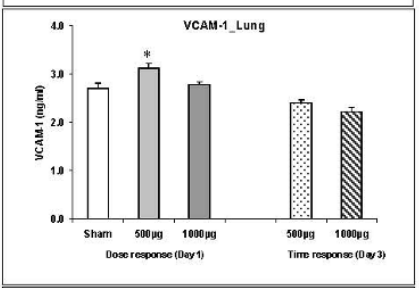

f)

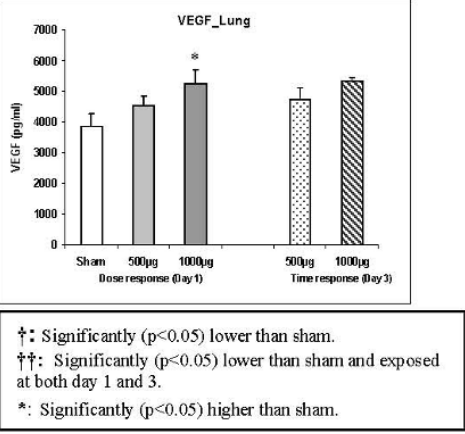

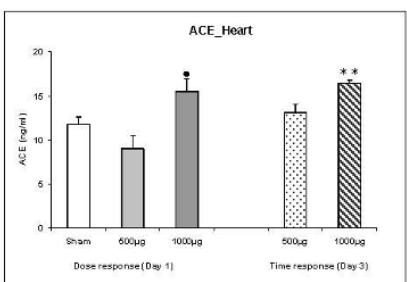
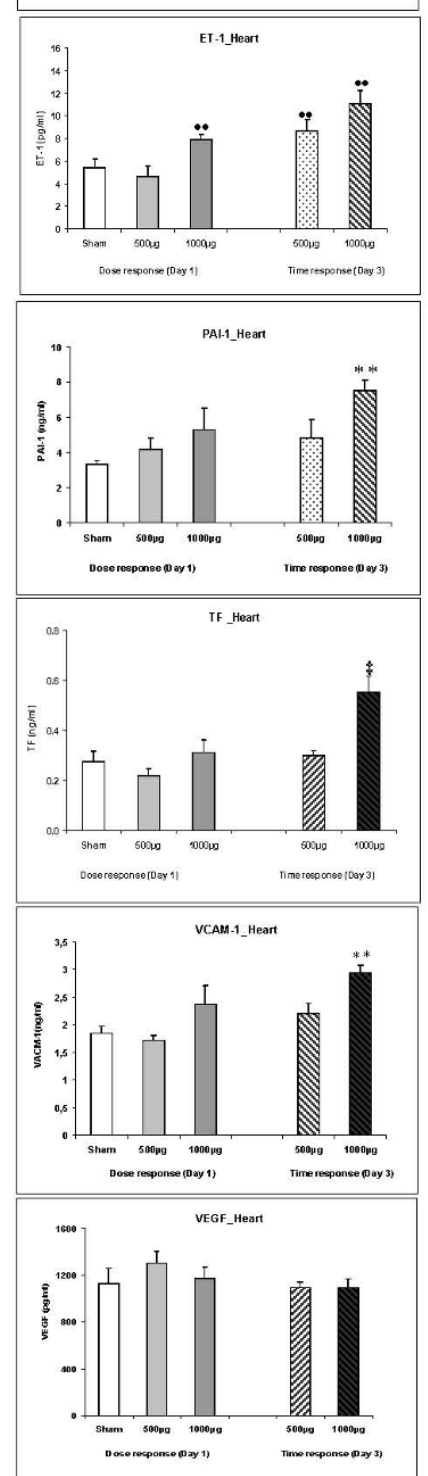

- : Significantly $(\mathrm{p}<0.05)$ higher than $500 \mu \mathrm{g}$ at $24 \mathrm{~h}$. -.: Significantly $(\mathrm{p}<0.05)$ higher than sham and $500 \mu \mathrm{g}$ a day 1. \$: Significantly $(\mathrm{p}<0.05)$ higher than sham and exposed at day 1 and 3 . "

Figure 7 Side by side comparison of the lung and heart response of angiotensin converting enzyme (ACE; 5a), Endothelin-1 (ET-1; $5 b)$, plasminogen activator inhibitor-1 (PAI-1; 5c), tissue factor (TF; 5d), vascular cell adhesion molecule-1(VCAM-1; 5e) and vascular

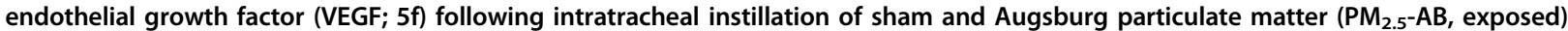
in spontaneously hypertensive rats (SHRs). Bars represent arithmetic mean values \pm SE of sham $(n=6)$ and exposure groups $(n=6)$. $\mathbf{~ : ~}$ Significantly $(p<0.05)$ lower than sham. $\mathbf{t + :}$ Significantly $(p<0.05)$ lower than sham and exposed at both day 1 and 3 . *: Significantly $(p<0.05)$ higher than sham. **: Significantly $(p<0.05)$ higher than sham and $500 \mu \mathrm{g}$ exposed at day 1 both day 1 and 3. $\because$ Significantly $(p<0.05)$ higher than $500 \mu \mathrm{g}$ at $24 \mathrm{~h} . \cdots$ : Significantly $(\mathrm{p}<0.05)$ higher than sham and $500 \mu \mathrm{g}$ at day 1 . ¥: Significantly $(\mathrm{p}<0.05)$ higher than sham and exposed at day 1 and 3 . 
Table 1 Representation of the response pattern (dose and time) of all the markers analyzed in lung and heart tissue following instillation of $500 \mu \mathrm{g}$ and $1000 \mu \mathrm{g}$ Augusburg dust in Spontaneously hypertensive rats (SHRs)

\begin{tabular}{|c|c|c|c|c|c|c|c|c|}
\hline \multirow[t]{3}{*}{ Protein } & \multicolumn{4}{|c|}{ Lung } & \multicolumn{4}{|c|}{ Heart } \\
\hline & \multicolumn{2}{|c|}{ Day1 } & \multicolumn{2}{|c|}{ Day3 } & \multicolumn{2}{|c|}{ Day1 } & \multicolumn{2}{|c|}{ Day3 } \\
\hline & $500 \mu \mathrm{g}$ & $1000 \mu \mathrm{g}$ & $500 \mu \mathrm{g}$ & $1000 \mu \mathrm{g}$ & $500 \mu \mathrm{g}$ & $1000 \mu \mathrm{g}$ & $500 \mu \mathrm{g}$ & $1000 \mu \mathrm{g}$ \\
\hline Interleukin 6 (IL-6) & 2.5 fold $\uparrow$ & 4.0 fold $\uparrow$ & n.s & n.s & n.d & n.d & n.d & n.d \\
\hline Osteopontin (SPP1) & n.s & 2.0 fold $\uparrow$ & n.s & n.s & n.s & n.s & n.s & 2.4 fold $\uparrow$ \\
\hline Macrophage inflammatory protein 2 (MIP2) & n.s & 1.3 fold $\uparrow$ & n.s & 1.3 fold $\uparrow$ & n.s & 1.5 fold $\uparrow$ & n.s & 2.0 fold $\uparrow$ \\
\hline Tumor necrosis factor alpha (TNF $\alpha$ & n.s & n.s & n.s & n.s- & n.s & n.s & n.s & n.s \\
\hline Angiotensin converting enzyme (ACE) & n.s & 1.3 fold $\downarrow$ & n.s & 3.0 fold $\downarrow$ & n.s & 1.4 fold $\uparrow$ & n.s & 1.4 fold $\uparrow$ \\
\hline Endothelin 1 (ET1) & 1.5 fold $\downarrow$ & 1.5 fold $\downarrow$ & 1.5 fold $\downarrow$ & 1.5 fold $\downarrow$ & n.s & 1.5 fold $\uparrow$ & 1.5 fold $\uparrow$ & 2.1 fold $\uparrow$ \\
\hline Plasminogen activator inhibitor 1 (PAl-1) & 1.5 fold $\uparrow$ & n.s & 2.4 fold $\downarrow$ & 6.5 fold $\downarrow$ & n.s & n.s & n.s & 2.0 fold $\uparrow$ \\
\hline Tissue factor (TF) & 1.5 fold $\downarrow$ & 1.5 fold $\downarrow$ & 1.5 fold $\downarrow$ & 1.5 fold $\downarrow$ & n.s & n.s & n.s & 2.0 fold $\uparrow$ \\
\hline Vascular cell adhesion molecule 1 (VCAM1) & 1.3 fold $\uparrow$ & n.s & n.s & n.s & n.s & n.s & n.s & 1.6fold $\uparrow$ \\
\hline Vascular endothelial growth factor (VEGF) & n.s & 1.5 fold $\uparrow$ & n.s & n.s & n.s & n.s & n.s & n.s \\
\hline
\end{tabular}

n.d: not detected; n.s: not significant.

findings are more generalized. However, the case-control study in survivors of myocardial infarction, by Peters et al. $(26,10)$ has reported that transient exposure to traffic may increase the risk of myocardial infarction. Myocardial infarction is an acute event predisposed due to chronic physiological impairment, like atherosclerotic lesions, a pro-coagulatory state and increased plasma viscosity. Therefore, in this work the experimental design was to study $\mathrm{PM}_{2.5}-\mathrm{AB}$ induced pathways potentially associated with the preceding cardiovascular events that eventually contribute to the observed fatal outcomes reported by epidemiology (Figure 8). In a first approach we focused on the acute response after a single instillation of moderate to high $\mathrm{PM}_{2.5}-\mathrm{AB}$ concentrations in the range of doses applied in other studies [35,36] supposed to cover the range of "no effects" to "obvious response" but being beyond the level of lung injury as shown by biological markers and histological examinations. To identify $\mathrm{PM}_{2.5}-\mathrm{AB}$ induced pathways we investigated two issues in a well established animal model (spontaneously hypertensive rats) of human cardiovascular disease: a) the dose-time dependent inflammatory response of $\mathrm{PM}_{2.5^{-}}$ $\mathrm{AB}$ in the lungs, on a systemic level and the target organ heart complemented by analysis of the cardiovascular performance by radiotelemetry and b) potential pathophysiological mechanisms affecting the cardiopulmonary system following $\mathrm{PM}_{2.5}-\mathrm{AB}$ exposure (Figure 8). We analysed all biomarkers at the protein level compared to mostly transcript based assessments in other studies.

High volume filter samples of ambient Augsburg dust were taken during September and October 2006 at an urban background site in Augsburg. This location has been carefully selected by comparing PM burdens at different urban background sites to find out a representative measurement site for Augsburg [37]. Moreover, since
2004 different online measurement methods were established at this site to characterize the physical and chemical properties of ambient Augsburg dust [38-43]. The main PM sources in urban areas are of anthropogenic origin and therefore a mixture of different particulate emissions like traffic, domestic heating and small-scale industry will be expected. Chemical analysis of PM from Augsburg urban area reported the presence of anthropogenic polycyclic aromatic hydrocarbons (PAH) and their oxidised derivatives (O-PAH).The online measurements during the sample period suggests a moderate PM exposure. For example, the $\mathrm{PM}_{2.5}$ mass concentration was 19.8 and $18.2 \mu \mathrm{g} / \mathrm{m}^{3}$ for the mean of the sample period. Traffic is well-known as an emission source of particle number concentration especially of ultrafine particles [39]. In our study the ultrafine particles concentrations were 10344 and $108021 / \mathrm{cm}^{3}$ for the mean of the sample period. The applied sample and resuspension technique (reference method of US-EPA) provided PM and the water soluble organic and inorganic constituents from ambient Augsburg PM to the rat lungs by instillation. Although the sampled $\mathrm{PM}_{2.5}$ includes the ultrafine particles fraction it is unlikely that sampling and preparation keeps ultrafine particles in its "airborne state" rather ultrafine particles may form aggregates with itself or fine particles but they may keep their surface toxicity.

\section{Cardiovascular performance}

As expected, cardiovascular effects in SHRs at high levels of $\mathrm{PM}_{2.5}-\mathrm{AB}$ were small and would, as a single event be clinically not relevant among subjects with adequate cardiovascular reserves, or even not in patients with cardiac diseases. However, triggering effects by repeated exposures over several years as given in the environmental setting of Augsburg may be one major factor contributing to the 


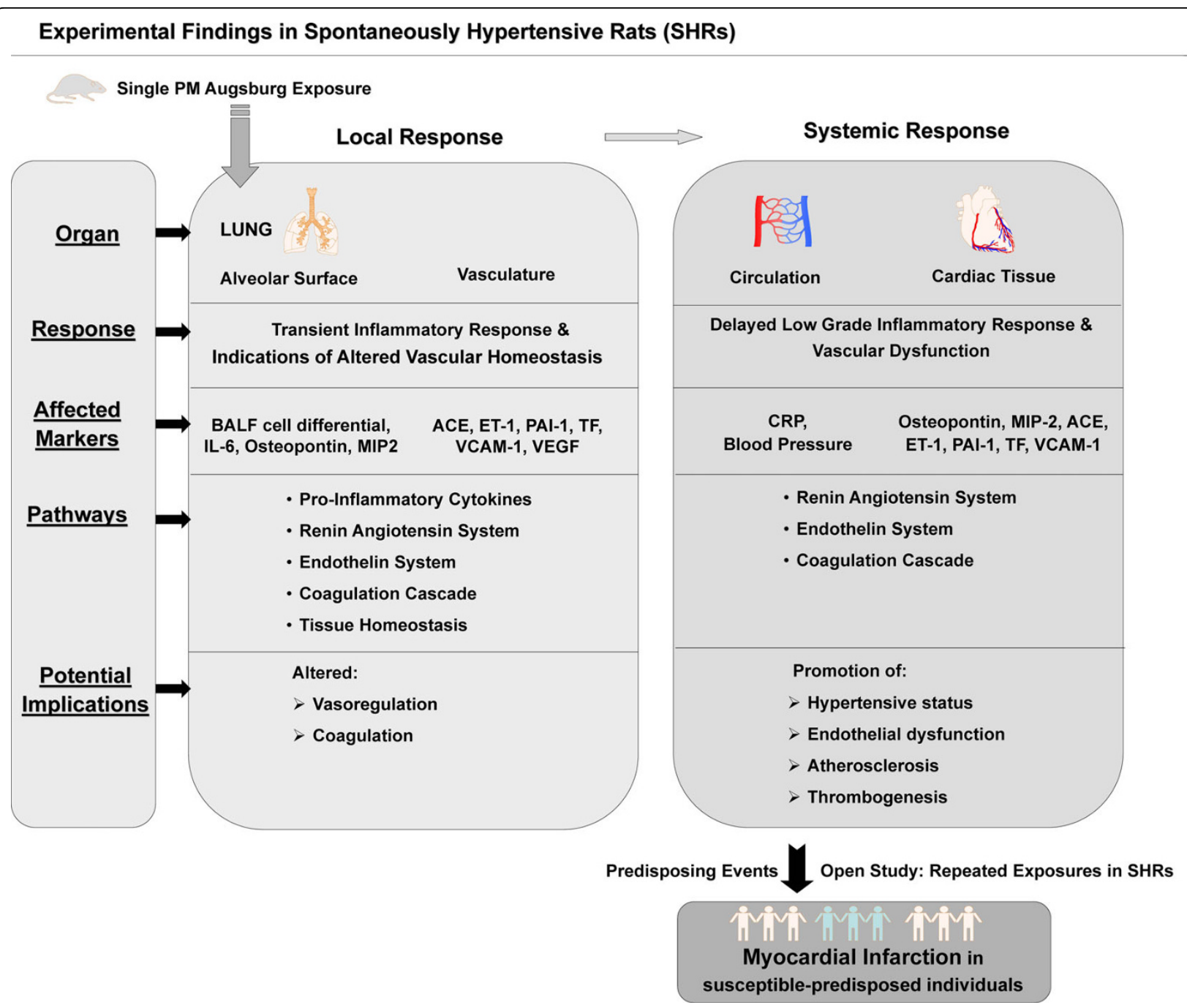

Figure 8 A schematic summarization of the results obtained from Augsburg dust exposures in spontaneously hypertensive rats (SHRs) in different organs are presented. BALF: Bronchoalveolar lavage fluid; IL-6: Interleukin-6; MIP-2: Macrophage inflammatory protein-2; ACE: Angiotensin converting enzyme; ET-1: Endothelin-1; PAI-1: Plasminogen activator inhibitor-1; TF: Tissue factor; VCAM-1: Vascular cell adhesion molecule-1 and VEGF: Vascular endothelial growth factor.

promotion of cardiovascular disorders as suggested by the epidemiological associations. The response in SHRs at high levels of $\mathrm{PM}_{2.5}-\mathrm{AB}$ was characterized by a $5 \%$ increase in $\mathrm{mBP}$ in exposed animals between the $2^{\text {nd }}-4^{\text {th }}$ post exposure days the maximum being on $4^{\text {th }}$ day after instillation. Changes in $\mathrm{mBP}$ were due to a moderate changes in systolic and diastolic BP. HR decreased by about $6 \%$ on the $3^{\text {rd }}$ day after instillation. However, the statistical analyses were not definitely decisive for these cardiovascular effects so that they have to be interpreted with caution and the results valued in context with the effects detected for markers of vascular homeostasis. In other experimental settings moderate HR and BP changes have repeatedly been reported in response to different PM [44-47] such as an increased HR and BP in SHRs exposed to ultrafine carbon particles [45] but also a decreased HR in response to highway aerosols [44]. The direction and time point of HR and BP differed between studies as the PM composition and fraction used suggesting that the cardiovascular response to ambient particle may result from a summation of temporally different effects of PM-associated components including direct interaction of translocated particles to pulmonary and systemic tissues $[48,49]$. The BP changes observed in the present study are in line with the epidemiological findings revealing a slight increased arterial BP in response to elevated levels of Augsburg PM [25], in particular in compromised subjects with high plasma viscosity levels. However, changes in epidemiological studies were detected at an earlier time point than in our experimental setting and HR rather increased than 
decreased [9]. Different factors one may speculate on may account for this, such as randomly selected population versus rats with distinct cardiovascular disease, species difference, route of PM exposure and particle translocation kinetics, but at hand it is beyond the scope of the present study to provide an obvious explanation.

\section{Pulmonary and systemic inflammatory responses}

A single Intratracheal instillation of $\mathrm{PM}_{2.5}-\mathrm{AB}$ was associated with a low grade dose-dependent pulmonary inflammation as indicated by accumulation of particleladen macrophages, lymphocytes, and PMNs resulting in a 2-fold induction of total cell numbers in BALF on the $1^{\text {st }}$ day post instillation. This cellular response was resolved within 3 days. In contrast, PM mediated in vivo toxicity screening studies in SRHs by Gerlofs-Nijland et al [36] reported a tremendous increase in PMN number in BALF 24-hr after exposure to the highest concentrations $(10 \mathrm{mg} / \mathrm{kg}$ bw i.t.) of EHC-93 (urban dust from Ottawa, Canada) or $\mathrm{PM}_{10}$ sampled nearby a road tunnel. This suggests that PM from Augsburg has less inflammatory potential and that the severity of health effects induced by PM from different sampling sites differs substantially between sites most likely due to differences in chemical composition and the relative share of the particle size fractions at the different sites.

The dose-dependent induction of the proinflammatory cytokine (IL-6) and the matricellular (matrix+cytokine: osteopontin; [50]) protein in BALF confirm the $\mathrm{PM}_{2.5}$ $\mathrm{AB}$ mediated pulmonary inflammation. Corresponding observations were made in the epidemiological studies in Augsburg [34,51] and have also been reported in other studies [30,52].

Panel and population studies have associated elevated PM levels with evidence of an acute-phase response inferred from increased serum CRP levels [20], enhanced plasma viscosity [17] and altered hematologic indices $[32,33,53,54]$. Epidemiological findings $[34,51]$ have suggested that the increased level of IL-6 following high ambient PM load possible leads to the production of acute phase proteins like CRP. This fits to observation made in the present study where peak IL- 6 concentrations in the BALF were observed on the 1st day after instillation of $\mathrm{PM}_{2.5}-\mathrm{AB}$ and highest CRP concentrations in serum after the 3rd day. In a recent study Zhao et al. [55] have reported that the levels of CRP in serum were significantly higher in SHRs than those in WKY following instillation of fine particle (8 and $40 \mathrm{mg} / \mathrm{kg}$; collected from Shanghai, China) supporting the notion that individuals with persisting cardiopulmonary disorder are at higher risk when exposed to the elevated level of PM than healthy ones.

Serum CRP concentrations reflect the burden of vascular inflammation. In the presence of an intercurrent illness or an exogenous inflammatory stimulus, serum
CRP concentrations increase rapidly as part of the systemic acute-phase reaction [56,57]. In recent years CRP has also come up as a leading biological marker of atherosclerosis, with serum CRP concentrations, even at very low levels, predicting the risk of acute myocardial infarction or stroke in apparently healthy individuals $[34,57]$. CRP seems to be a strong predictor of cardiovascular events in humans. Using widely available highsensitivity assays, CRP levels of $<1,1$ to 3 , and $>3 \mathrm{mg} / \mathrm{L}$ correspond to low-, moderate-, and high-risk groups for future cardiovascular events in human [58]. We are not aware of such grading for rodents. But if we extrapolate from the available information in humans, a $\sim 4$ fold induction of serum CRP on the 3rd day post instillation of $1000 \mu \mathrm{g} \mathrm{PM}_{2.5}-\mathrm{AB}$ suggests high risk for cardiovascular impairment in SHRs.

The time and dose dependent induction of MIP-2 and osteopontin in cardiac tissue suggests that the $\mathrm{PM}_{2.5}-\mathrm{AB}$ mediated sustained systemic inflammatory response also involves cardiac tissue. Although cellular mechanism of systemic inflammation are very complex, a number of researchers reported that the induction of chemokine (MIP-2) and the upregulation of matricellular protein (ostopontin) are involved in the recruitment and stimulation of neutrophil, macrophage, and lymphoctes after particle exposure [59].

The present findings are consistent with a series of studies suggesting that intratracheal instillation of PM in rodents caused pulmonary and systemic inflammation [60-63]. Effect of pulmonary PM exposure by inhalation may be with/without systemic inflammatory response [45]. This is mainly due to the lower dosage delivered to the lungs over a longer period but the observed effect also depend on the chemical composition, presence of water-soluble metals and surface area of the particles as shown in various studies [62-64].

\section{Responses affecting vascular homeostasis}

Potential pathways linking the observed pulmonary and systemic events are identified by analysis of various biomarkers associated with hypertension (ACE), endothelial activation (ET-1), coagulation factors (TF; PAI-1), atherosclerosis (VACM-1) and angiogenesis (VEGF) from pulmonary and cardiac tissues. Protein analysis of these markers in cardiac tissues revealed a delayed systemic response while the same markers responded differently or to a lesser extent in pulmonary tissues. This result illustrates the $\mathrm{PM}_{2.5}-\mathrm{AB}$-specific differences in the degree and time course of pulmonary and cardiac effects. Studies from Wallenborn et al. [64] support our observation. They specifically addressed the differential pulmonary and cardiac effects of intratracheal instilled metals in WKY rats ( 1 micromol/ $\mathrm{kg}$ body weight of zinc, nickel, vanadium, copper, or iron in sulfate form). 
Depending on the metal species applied, the severity and the time point of pulmonary inflammation varied. Similarly, the systemic effects noted for zinc, nickel or copper occurred at different time points.

In pulmonary tissue a transient and early induction of PAI-1, VEGF, and VCAM-1 and a decline in ACE, ET-1, and TF concentrations suggests direct involvement of the pulmonary vasculature in the $\mathrm{PM}_{2.5}-\mathrm{AB}$ response. Reduced ACE and ET-1 levels may indicate a vasodilation response as similar to the other studies $[65,66]$. Increased expression of PAI-1 in the vasculature has been recognized as indicator of disturbed endothelial function [67] and associated with the progression of atherosclerotic lesions [68,69]. Many studies have shown that alteration of the VEGF homeostasis is involved in different pathological states of pulmonary tissues, such as acute lung injury and pulmonary arterial hypertension [70,71]. A moderate upregulation of VEGF - as observed in our study - is often regarded as a protective mechanism to restore tissue homeostasis because VEGF serves as a survival and differentiation factor for pulmonary endothelial cells $[70,72]$. Up-regulation of VCAM-1 in the pulmonary tissue might be due to the activation of endothelial cell by cytokines released from activated macrophages or recruited PMNs [70]. Different studies [73-75] have provided evidence that VCAM1 promotes the progression of atherosclerosis by accumulation, adhesion and trans-endothelial migration of leukocytes. Furthermore, activated endothelial cells can increase the expression of PAI-1, VEGF and VACM-1 $[70,76]$ and might be responsible for development of atherosclerosis lesion.

Interestingly, in the heart all measured markers (except VEGF) were increased at high concentrations on day 3 post exposure. The observed increased levels of PAI-1, known to be an inhibitor of fibrinolysis and regulator of vasoactivity, have been recognized as indication of impaired endothelial function [67]. The additionally observed induction of $\mathrm{TF}$, the extrinsic coagulation pathway, is highly correlated with thrombogenesis and endothelial dysfunction $[77,78]$. Therefore activation of TF in association with impaired fibrinolysis via PAI-1 activation following $\mathrm{PM}_{2.5}-\mathrm{AB}$ exposure supports the notion of endothelial dysfunction, which is importantly correlated with overall cardiovascular risk [77,79]. Endothelial dysfunction by PM in cardiac tissue can be further inferred from induction of ET-1 and activation of the ACE system in cardiac tissue following instillation of high $\mathrm{PM}_{2.5}-\mathrm{AB}$. Interestingly, the slight increase in $\mathrm{BP}$ follows the kinetics of ACE and ET-1 concentrations in serum. ACE and other components of the RAS (including rennin and angiotensin II receptor) are expressed in the several organs (e.g. lung, heart, brain) and play a significant role in the regulation of systemic BP and endothelial homeostasis. Several studies reported that RAS system plays a key role in ET-1 expression and might also be responsible for up-regulation of ETB receptors [80,81]. Overall, $\mathrm{PM}_{2.5}-\mathrm{AB}$ exposure at high concentration affects different endpoints of the vascular homeostasis in the lungs and the systemic circulation by triggering pathways known to be involved in endothelial dysfunction, vasoregulation, and thrombogenesis.

In this study physiological parameters like HR and HRV responded differently compared to our previous ultrafine carbon particle inhalation study in SHRs [45]. Additionally we detected alteration at molecular level to be more pronounced in cardiac tissue compared to pulmonary tissue previously. This may be related to the different age groups (12 months versus 6 months) of animals investigated and plausibly because of the altered organ functions due to hypertension. But it's more likely that beside carbon particles other ambient PM2.5 components from Augsburg are involved in the observed systemic response [82]. Chemical analysis of PM from Augsburg urban area reported the presence of anthropogenic polycyclic aromatic hydrocarbons (PAH) and their oxidised derivatives (O-PAH, 40-43). Concentrations of $\mathrm{PAH}$ and O-PAH in PM were highly correlated to ROS formation, which is known to be involved in inflammatory responses in the lungs and extrapulmonary organs [83]. Beside that $\mathrm{PM}_{2.5}-\mathrm{AB}$ contains various transition metals which may move as soluble components directly through the pulmonary vasculature and reach the systemic circulation where the metals exert direct effects on extrapulmonary tissue $[62,64]$.

\section{Conclusion}

Although there are some differences between the effects observed in our animal study and the effects detected by epidemiological studies in Augsburg, overall, there is clear evidence that many different pathways are triggered in our model which play an important role in cardiovascular impairment and fatal events. A schematic summarization of the results obtained from Augsburg dust exposures in SHRs in different organs are presented in Figure 8. The scheme mechanistically links the observations obtained in this study as potential underlying factors for the fatal cardiovascular events recognized in epidemiological studies. As observed in many experimental studies $\mathrm{PM}_{2.5}-\mathrm{AB}$ instillation induced a transient inflammatory response in the lungs which was largely resolved within 3 days. VEGF was moderately increased presumably involved in restoration of lung tissue homeostasis, whereas continued effects are still observed in the pulmonary vasculature. They were associated with coagulation activity and vasoregulatory pathways including the renin-angiotensin system. Secondary systemic effects were characterized by a delayed, low grade systemic inflammatory response not only involving the 
vascular compartment (CRP) but also in cardiac tissue (Osteopontion, MIP-2). Through the induction of the coagulation cascade (PAI-1, TF, VCAM-1) and vasoregulatory activities (ACE, ET-1) $\mathrm{PM}_{2.5}-\mathrm{AB}$ transiently augments the hypertension and may contribute to the development and progression of atherosclerotic lesions. These acute effects underpin the atherothrombotic consequences of acute exposure to PM2.5- $\mathrm{AB}$ on cardiovascular disease. Although the chronic exposure as missing link is lacking and beyond the scope of the present study it is reasonable to consider effects of a single exposure to be small and, taken as an unique event, to be clinically of minor importance. However, repeated exposures over several years as given in the environmental setting of Augsburg is supposed to add up over time [84] and promote cardiovascular disorders in susceptible-predisposed individuals, which may eventually contribute to trigger fatal cardiac events such as myocardial infarction documented in the epidemiological studies (Figure 8).

\section{Materials and methods Sampling Location}

The sample site was placed on the campus of the University of Applied Sciences Augsburg which is approximately $1 \mathrm{~km}$ to the south-east of the city centre. Within a radius of $100 \mathrm{~m}$ it is surrounded by campus buildings, a tram depot and a small company. The nearest main road is in the north-east at a distance of $100 \mathrm{~m}$. Within a radius of approximately $200 \mathrm{~m}$ the monitoring site is almost completely surrounded by residential areas, apart from a small park located in north-western direction.

\section{PM sampling}

We used a High Volume Sampler (HVS, model DHA-80, DIGITEL Elektronik AG, Switzerland) equipped with a $\mathrm{PM}_{2.5}$ pre-separator (one-stage impactor certificated according to EN12341) to collect $\mathrm{PM}_{2.5}$ samples on filters (diameter $150 \mathrm{~mm}$ ). The flow rate of the HVS was adjusted to $30 \mathrm{~m}^{3} / \mathrm{h}$ and automatic regulated. After sampling the filters were frozen at $-20^{\circ} \mathrm{C}$ for further resuspension.

The sampling period started on the $18^{\text {th }}$ of September 2006 and ended on the $16^{\text {th }}$ of October 2006. In total 8 filters were available for an alternating sampling period of 3 and 4 days.

\section{Ambient concentrations (mass concentration of $\mathrm{PM}_{2.5}$, number concentrations of ultrafine particles)}

The mass concentration of $\mathrm{PM}_{2.5}-\mathrm{AB}$ was measured using a tapered element oscillating microbalance (TEOM, model 1400ab, Thermo Fisher Scientific Inc., U. S.) equipped with a $\mathrm{PM}_{2.5}$ inlet. To correct the PM measurement for aerosol volatility effects, the TEOM was equipped with a filter dynamics measurement system
(FDMS, model 8500b, Thermo Fisher Scientific Inc., U. S.).

The UFP number concentration was calculated from the particle size distribution measured with a twin differential mobility particle sizer (TDMPS) system. The TDMPS system consists of two subsystems covering different size ranges.

Details on the used online measurement devices and further information about other continuously measured physical and chemical parameters were already published by Pitz et al. [38,39].

\section{Animals}

Male spontaneously hypertensive rats (SHR) were used for the present study. Animals were housed under filtered air and specific pathogen free (SPF) conditions at a mean temperature of $22 \pm 2^{\circ} \mathrm{C}$, a mean relative humidity of $50 \pm 5 \%$, and a $12 \mathrm{~h}$ light-dark cycle $(6$ a.m. to 6 p.m. light on) with pelleted feed and filtered water being supplied ad libitum. Experimental protocols were approved by the Animal Care and Use Committee of the HelmholtzZentrum München - German Research Center for Environmental Health and by the Bavarian Animal Research Authority (211-2531-88/2007). Animals were 12-months of age with body weights between 360-380 g during the study.

\section{Intra-tracheal instillation study}

To assess the inflammatory response following instillation of ambient particle two animal groups were used. In this study 1 year old male SHRs of Group A (Sham/ exposed: $n=8 / 8$; Table 2) were IT-instilled with either pyrogene-free distilled water (sham) or water suspension of ambient particle $\left(\mathrm{PM}_{2.5}-\mathrm{AB}\right)$ at $250 \mu \mathrm{g}, 500 \mu \mathrm{g}$ and $1000 \mu \mathrm{g}$ under isoflurane anaesthesia and lavage were performed at $24 \mathrm{~h}$ or day 1 postinstillation. Similarly Group B (Sham/exposed: $n=8 / 8$; Table 2) animals were IT-instilled either pyrogene-free distilled water (sham) or water suspension of ambient particle $\left(\mathrm{PM}_{2.5}-\mathrm{AB}\right)$ at $500 \mu \mathrm{g}$ and $1000 \mu \mathrm{g}$ under isoflurane anaesthesia and lavage were performed at $72 \mathrm{~h}$ or day 3 postinstillation. Additionally we have performed cardiovascular response study following instillation of pyrogene-free distilled water (sham; $\mathrm{n}=5$ ) and $1000 \mu \mathrm{g}$ of particle (exposed; $\mathrm{n}=5$ ), as inflammatory response were more pronounced at $1000 \mu \mathrm{g}$. For intra-tracheal instillation SHRs were anesthetized by administration of isofluran $(5.0 \%$ isoflurane in O2; Sigma Delta Vaporizer; Uno, Zevenaar, Netherlands) using a customized flow-through mask (Helmholtz-Zentrum München, Neuherberg, Germany). The animals were then intubated by a nonsurgical technique [85] using a bulb headed cannula inserted $10 \mathrm{~mm}$ into the trachea; $250 \mu \mathrm{l}$ of a suspension containing 250 , 500 and $1000 \mu \mathrm{g}$ particles, respectively, in pyrogene-free distilled water was instilled individually in each animal. The suspension of particles was sonicated for $1 \mathrm{~min}$ 
Table 2 Experimental design of cardio physiological, pulmonary and systemic response

\begin{tabular}{|c|c|c|c|c|c|c|c|c|}
\hline \multicolumn{9}{|c|}{ Instillation } \\
\hline \multirow[b]{2}{*}{ Cardiovascular response } & \multicolumn{2}{|c|}{ Adaptatiion } & \multirow{2}{*}{$\begin{array}{c}\text { Baseline } \\
\text { Day } 0\end{array}$} & \multicolumn{5}{|c|}{ Post exposure } \\
\hline & Day -2 & Day-1 & & Night 1 & Night 2 & Night 3 & Night 4 & Night 5 \\
\hline & \multicolumn{2}{|c|}{ Acclimatization } & $\sqrt{ }$ & $\sqrt{ }$ & $\sqrt{ }$ & $\sqrt{ }$ & $\sqrt{ }$ & $\sqrt{ }$ \\
\hline \multirow[t]{2}{*}{ Telemetry $(n=5)^{*}$} & \multicolumn{2}{|c|}{ No change } & $\mathrm{BP}$ & $\mathrm{BP}$ & $\mathrm{BP}$ & $\mathrm{BP}$ & $\mathrm{BP}$ & $\mathrm{BP}$ \\
\hline & & & $H R$ & $H R$ & $\mathrm{HR}$ & $\mathrm{HR}$ & $\mathrm{HR}$ & $H R$ \\
\hline \multicolumn{9}{|c|}{ ambient particle-mediated pulmonary and systemic response } \\
\hline Pulmonary resposne & \multicolumn{3}{|c|}{ Day 1 (24 h; Group A) } & & \multicolumn{4}{|c|}{ Day 3 (72 h; Group B) } \\
\hline Dose/rat & $250 \mu \mathrm{g}$ & & $500 \mu \mathrm{g}$ & $1000 \mu \mathrm{g}$ & & $500 \mu \mathrm{g}$ & $1000 \mu \mathrm{g}$ & \\
\hline $\operatorname{BALF}(n=6)$ & $\sqrt{ }$ & & $\sqrt{ }$ & $\sqrt{ }$ & & $\sqrt{ }$ & $\sqrt{ }$ & \\
\hline Lung tissue $(n=6)$ & $\sqrt{ }$ & & $\sqrt{ }$ & $\sqrt{ }$ & & $\sqrt{ }$ & $\sqrt{ }$ & \\
\hline Pulmonary histopathology $(n=2)$ & $\sqrt{ }$ & & $\sqrt{ }$ & $\sqrt{ }$ & & $\sqrt{ }$ & $\sqrt{ }$ & \\
\hline \multicolumn{9}{|l|}{ Systemic response } \\
\hline Blood $(n=8)$ & $\sqrt{ }$ & & $\sqrt{ }$ & $\sqrt{ }$ & & $\sqrt{ }$ & $\sqrt{ }$ & \\
\hline Cardiac tissue $(n=6)$ & $\sqrt{ }$ & & $\sqrt{ }$ & $\sqrt{ }$ & & $\sqrt{ }$ & $\sqrt{ }$ & \\
\hline Cardiac histopathology $(n=2)$ & $\sqrt{ }$ & & $\sqrt{ }$ & $\sqrt{ }$ & & $\sqrt{ }$ & $\sqrt{ }$ & \\
\hline
\end{tabular}

*Number of exposed animals is given. A similar number of animals were intratrachealy instilled with pyrogene-free distilled water and served as controls or sham. Blood : blood collected from retro arbitral sinus and abdominal aorta.. BP and HR: blood pressure and heart rate were the two primary parameters measured for the cardiovascular response.

prior to each instillation, using an ultrasonic bath SonoPlus HD70 (Bachofer, Berlin, Germany) at a moderate energy of $20 \mathrm{~W}$. We favour the use of pyrogene-free distilled water for suspension of particles because the salt content of phosphate-buffered saline (PBS) causes rapid particle agglomeration comparable to the "salting-out" effect [63] and thus eliminates consistent instillation conditions. Control (sham) animals were instilled with pyrogene-free distilled water.

\section{Assessment of ambient particle-mediated pulmonary}

\section{inflammatory response}

BALF and lung BALF analysis was performed on day 1 (24h: group A) and day 3 (72h: group B) after instillation as described in our previous study $[45,86]$. In brief, one aliquot of whole BALF $(n=6)$ was used for determining total cell counts (Coulter Counter; Coulter, Inc., Miami, FL), and a second aliquot was centrifuged (Cytospin 2; Shandon, Astmoor, UK) to counts cell differential. Macrophages, polymorphonuclear cells (PMNs, or neutrophil), eosinophil, and lymphocyte were counted using light microscopy (over 200 cells counted per slide). The remaining BALF was centrifuged $(1500 \times \mathrm{g})$ to remove cells, and the supernatant fluids were analyzed for osteopontin (Catalog \# 900-089; Biomol) and IL-6 (Catalog \# 550319; BD-Bioscience) concentration, as potential biological markers for pulmonary inflammation. Furthermore, transcript profiling markers associated with pulmonary inflammation (MIP-2, TNF- $\alpha$ ), were also assessed at protein level from the pulmonary tissues $(n=6)$ using the Rodent MAP version 2.0-custom 8-plex of the Rules Based Medicine (Austin, Texas).

Pulmonary histopathology The left lung of each non lavaged animal $(n=2)$ was infused via left main bronchus by $4 \%$ buffered formalin at $20 \mathrm{~cm}$ water pressure for 20-30 minutes. The main bronchus was then tied and the lung was submerged in fixative until processing for histology. Paraffin blocks were prepared from dehydrated tissues and 3- to 4- $\mu$ m sections were stained with hematoxylin and eosin for light microscopic evaluation of the pulmonary tissues $[45,86]$..

\section{Assessment of ambient particle-mediated effects on} pulmonary and cardiac tissue

Protein analysis For protein analysis lung and cardiac tissues were collected from each animals $(n=6)$ immediately after BALF collection, placed in vials and flash frozen in liquid nitrogen. They were then stored at $-80^{\circ} \mathrm{C}$ until lung and heart tissue homogenates were prepared.

Pulmonary and Cardiac tissue homogenate preparation Total lung and heart homogenate was prepared using $50 \mathrm{mM}$ Tris-HCL with $2 \mathrm{mM}$ EDTA, pH 7.4 as the lysis buffer $(1000 \mu \mathrm{l})$ from 6 animals/experimental group. Using the Rodent MAP $^{\mathrm{TM}}$ version 2.0-custom 8-plex of the Rules Based Medicine (Austin, Texas) a panel of inflammatory and biomarkers (protein) associated with hypertension (ACE), endothelial activation (ET-1), coagulation factors (TF; PAI-1), atherosclerosis (VACM-1) and angiogenesis (VEGF) were analyzed from the lung and heart homogenate. Lung and heart homogenate of the $n$ 
$=6 / 6$ (sham/exposed) were used for the measurment and only the markers equal to/above $(\geq)$ the sensitivity level were considered. Sensitivity level is the least detectable dose (LDD) as provided by Rules Based Medicine. In all cases a strong homogeneity of data were observed. Osteopontin (SPP1) was also assayed from the heart homogenate samples by ELISA (Catalog \# 900089; Biomol).

Cardiac histopathology The whole heart of each non lavaged animal $(\mathrm{n}=2)$ was submerged in fixative until processing for histology. Paraffin blocks were prepared from dehydrated tissues and 3- to 4- $\mu \mathrm{m}$ sections were stained with hematoxylin and eosin for light microscopic evaluation of the cardiac histopathology [86].

Assessment of ambient particle-mediated systemic response Haematological analysis, measurement of different biomarkers from plasma and serum were used for the assessment of systemic response following $\mathrm{PM}_{2.5}-\mathrm{AB}$ exposure. Blood samples of each animal were collected from retro orbital sinus (haematology) and from abdominal aorta (biomarkers) on day 1 and day 3 after instillation.

Haematology For haematological analysis, $500 \mu \mathrm{l}$ of blood sample from retro orbital sinus of each animal $(n=8)$ was collected in EDTA-Microvette and analysed by using haematology analyzer (Bayer ADVIA 120, Germany).

Acute phase proteins analysis Blood samples collected from each animal $(\mathrm{n}=8)$ were stored in aliquots of 2.6 $\mathrm{ml}$ in $2.9 \mathrm{ml} \mathrm{S}$-Monovette ${ }^{\circ}$ tube (Sarstedt, Germany) without anticoagulant for further analysis of biomarker. C-reactive protein (CRP) was analysed from serum collected from blood samples after centrifugation for 15minutes (at $1300 \mathrm{~g}, 4^{\circ} \mathrm{C}$ ). CRP was measured by ELISA (Catalog\#: 557825, Biomol). Furthermore, the markers associated with systemic inflammation (MIP-2, TNF- $\alpha$ ), were also assessed at protein level from the cardiac tissues $(\mathrm{n}=6)$ using the Rodent $\mathrm{MAP}^{\mathrm{mi}}$ version 2.0-custom 8-plex of the Rules Based Medicine (Austin, Texas).

\section{Cardiophysiological analysis by radiotelemetry Exposure protocol}

Cardiophysiological response prior to and following instillation of ambient particle $(1000 \mu \mathrm{g} / \mathrm{rats})$ was performed on 12 months old SHRs by using radio telemetric system as described in our previous study (86, Dataquest A.R.T; Data Sciences International D.S.I., St. Paul MN, U.S.A). The implantation of telemetric devices into the peritoneal cavity of animals was performed as previously described [86]. All animals exhibited rapid post surgical recovery, with resumption of normal food and water intake within $24 \mathrm{~h}$ of surgery. They returned to presurgical body weight (excluding the weight of the implant) on average within 3-4 days and did not exhibit any signs of post surgical complications.
After 10 days of post surgical recovery, 10 animals were randomly assigned to the control (sham) or the exposure group, respectively. Data recording was then initiated and continued for six days, that included a baseline reading (day 0), and post exposure period readings (days 1-5) after instillation of pyrogene-free distilled water (sham) or $1000 \mu \mathrm{g}$ ambient particle (exposed, Figure 2). In this study separate animal groups $(n=5)$ were used for sham (instilled with water) and exposed (instilled with $1000 \mu \mathrm{g}$ particle) SHRs.

\section{Animal preparation, data acquisition and analysis using radio telemetry system}

The implantation of telemetric devices into the peritoneal cavity of animals (sham/exposed: $n=5 / 5$ ), the radio telemetric data acquisition and analysis were performed as described previously $[45,86]$. Briefly, arterial BP, HR, body core temperature (T), and physical activity $(A c t)$ of SHRs were continuously collected over $24 \mathrm{~h} /$ day, throughout baseline and after instillation for 5 days. Systolic (sBP), diastolic $(\mathrm{dBP})$, and mean $(\mathrm{mBP})$ arterial blood pressure were determined from the BP tracings on a beat to beat basis. The data of each animal were then processed to obtain 10-minutes average segments per rat for each of the measured parameters. For the final data analysis, we only have considered the values of each parameter from the $12 \mathrm{~h}$ dark period ( 6 p.m. to 6 a.m.), as animals are more active during the night time. Thereby, 72 consecutive values of 10-minutes data segments were obtained per rat per day and per parameter. Since we did not observe a time dependency of particle associated effects during the $12 \mathrm{~h}$ period in each of the exposed animals, mean values were used for further data processing. For all of the measured parameters, we averaged the 72 values obtained for each day resulting in one mean value per parameter per rat and per day. Based on these values, group mean were calculated on a daily bases for the whole study and were used for statistical comparison between sham (pyrogene-free distilled water) and exposed (1000 $\mu$ g particle) SHRs.

For heart-rate variability (HRV) analysis, a different procedure has to be applied [86]. For the $12 \mathrm{~h}$ dark periods, one 5-minutes ECG segment per hour was randomly selected and used for further HRV analysis. For each of these 5-minutes segments the standard deviation of all adjacent normal sinus NN intervals (SDNN) was determined as a measure of the overall HRV. In addition, the square root of the mean of squared differences between adjacent normal to normal intervals (RMSSD) and the low-frequency to high-frequency ratio (LF/HF), reflecting the balance of cardiac parasympathetic tone and sympathetic activity, respectively, were determined. Further data processing to obtain daily averages for each of the rats and group averages followed the procedure described above for the other parameters. 


\section{Statistics}

After checking for the normal distribution assumption the differences between exposure and control (sham) groups were compared by using the t-test. Cardiovascular response parameters were described by a linear mixed regression model for repeated measurements. Based on this model group differences between the exposure and control group were tested. To assess whether systematic BP and hear rate changes occur after $\mathrm{PM}_{2.5}$ instillation area under the curve (AUC) statistics was applied as an summary indicator of systematic changes for repeated measurements. For protein analysis of various parameters from lung and heart tissues, a two-way analysis of variance (ANOVA) was used to analyze differences between the groups. $\mathrm{P}$ values less than 0.05 were stated as statistically significant. All computations were done by the software packages Statgraphics plus v5.0 (Manugistics, Rockville, MD) and SAS V9.1 (Cary, NC). Data are presented as arithmetic mean values of $n$ observations \pm the standard error $(\mathrm{SE})$, unless otherwise indicated.

\section{About the authors}

From the Comprehensive Pneumology Center, Institute of Lung Biology and Disease (SU, KG, ST, MSB, TS, WGK, OE, HS); Focus Network: Nanoparticles and Health (WGK, HEW, HS), Institute of Epidemiology (MP, AP, HEW), Institute of Health Economics and Health Care Management (PR),. Helmholtz Zentrum Munich: German Research Center for Environmental Health.

\footnotetext{
Acknowledgements

The authors sincerely acknowledge the expert technical assistance received from Dr. Ines Bolle, Birgit Frankenberger, Maria Neuner, Baerbel Ritter, and Martina Schreiber. The authors also acknowledge the support and cooperation received from Dr. Georg Matuschek for providing the Augsburg particles.

This work was designed and coordinated within the Focus Network Nanoparticles and Health, Helmholtz Zentrum München, German Research Center for Environmental Health
}

\section{Author details \\ ${ }^{1}$ Comprehensive Pneumology Center, Institute of Lung Biology and Disease, Helmholtz Zentrum München, German Research Center for Environmental Health, Ingolstaedter Landstrasse 1, D85764, Neuherberg/Munich, Germany. ${ }^{2}$ Focus Network Nanoparticles and Health, German Research Center for Environmental Health, Neuherberg, Germany. Ingolstaedter Landstrasse 1, D85764, Neuherberg/Munich, Germany. ${ }^{3}$ Institute of Epidemiology, Helmholtz Zentrum München, German Research Center for Environmental Health, Ingolstaedter Landstrasse 1, D85764, Neuherberg/Munich, Germany. ${ }^{4}$ Institute of Health Economics and Health Care Management, Helmholtz Zentrum München, German Research Center for Environmental Health, Neuherberg, Germany. Ingolstaedter Landstrasse 1, D85764, Neuherberg/ Munich, Germany.}

\section{Authors' contributions}

SU KG, TS, MP, PR, WGK, AP, HEW, HS conceived and designed the experiments. SU, KG, TS, ST, MSB, MP performed the experiment; SU, KG, TS, ST, PR, MP, HS analyzed the data; SU, KG, TS, MP, WGK, OE, HEW, HS wrote the manuscript.
All authors read and approved the final manuscript.

\section{Competing interests}

The authors declare that they have no competing interests.

Received: 17 May 2010 Accepted: 29 September 2010

Published: 29 September 2010

\section{References}

1. WHO: The World Health Report. Reducing Risks, Promoting Healthy Life. Geneva, Switzerland: World Health Organisation 2002.

2. Dockery DW, Pope CA III, Xu X, Spengler JD, Ware JH, Fay ME, Ferris BG Jr, Speizer FE: An association between air pollution and mortality in six US cities. N Engl J Med 1993, 329:1753-1759.

3. Samet JM, Dominici F, Curriero FC, Coursac I, Zeger SL: Fine particulate air pollution and mortality in 20 US cities1987-1994. N Engl J Med 2000, 343:1742-1749.

4. Pope CA, Muhlestein JB, May HT, Renlund DG, Anderson JL, Horne BD: Ischemic heart disease events triggered by short-term exposure to fine particulate air pollution. Circulation 2006, 114(23):2443-2448.

5. Peters A, von Klot S, Heier M, Trentinaglia I, Cyrys J, Hörmann A, Hauptmann M, Wichmann HE, Löwel H: Particulate air pollution and nonfatal cardiac events. Part I. Air pollution, personal activities, and onset of myocardial infarction in a case-crossover study. Res Rep Health Eff Inst 2005, , 124: 1-66, discussion 67-82, 141-148.

6. Pope CA III, Burnett RT, Thun MJ, Calle EE, Krewski D, Ito K, Thurston GD: Lung cancer, cardiopulmonary mortality, and long-term exposure to fine particulate air pollution. JAMA 2002, 287:1132-1141.

7. Sandhu RS, Petroni DH, George WJ: Ambient particulate matter, C-reactive protein, and coronary artery disease. Inhal Toxicol 2005, 17:409-413.

8. Dockery DW, Luttmann-Gibson $\mathrm{H}$, Rich DQ, Link MS, Mittleman MA, Gold DR, Koutrakis P, Schwartz JD, Verrier RL: Association of air pollution with increased incidence of ventricular tachyarrhythmias recorded by implanted cardioverter defibrillators. Environ Health Perspect 2005, 113(6):670-4.

9. Peters A, Perz S, Döring A, Stieber J, Koenig W, Wichmann H-E: Increases in heart rate during an air pollution episode. Am J Epidemiol 1999 150:1094-8.

10. Peters A, Dockery DW, Muller JE, Mittleman MA: Increased particulate air pollution and the triggering of myocardial infarction. Circulation 2001 103:2810-2815.

11. von Klot S, Peters A, Aalto P, Bellander T, Berglind N, D'Ippoliti D, Elosua R, Hörmann A, Kulmala M, Lanki T, Löwel H, Pekkanen J, Picciotto S, Sunyer J, Forastiere F: Ambient air pollution is associated with increased risk of hospital cardiac readmissions of myocardial infarction survivors in five European cities. Circulation 2005, 112:3073-3079.

12. Zanobetti A, Schwartz J: The effect of particulate air pollution on emergency admissions for myocardial infarction: a multicity casecrossover analysis. Environ Health Perspect 2005, 113:978-982.

13. André E, Stoeger T, Takenaka S, Bahnweg M, Ritter B, Karg E, Lentner B, Reinhard C, Schulz H, Wjst M: Inhalation of ultrafine carbon particles triggers biphasic pro-inflammatory response in the mouse lung. Eur Respir J 2006, 28(2):275-85, Epub 2006 Apr 26.

14. Stenfors N, Nordenhall C, Salvi SS, Mudway I, Soderberg M, Blomberg A, Helleday R, Levin JO, Holgate ST, Kelly FJ, Frew AJ, Sandstrom T: Different airway inflammatory responses in asthmatic and healthy humans exposed to diesel. Eur Respir J 2004, 23:82-86.

15. Schulz H, Harder V, Ibald-Mulli A, Khandoga A, Koenig W, Krombach F, Radykewicz R, Stampfl A, Thorand B, Peters A: Cardiovascular effects of fine and ultrafine particles. J Aerosol Med 2005, 18:1-22.

16. Salvi S, Holgate ST: Mechanisms of particulate matter toxicity. Clin Exp Allergy 1999, 29:1187-1194.

17. Peters A, Döring A, Wichmann HE, Koenig W: Increased plasma viscosity during an air pollution episode: a link to mortality? Lancet 1997, 349:1582-1587.

18. Seaton A, MacNee W, Donaldson K, Godden D: Particulate air pollution and acute health effects. Lancet 1995, 345:176-178.

19. Nurkiewicz TR, Porter DW, Barger M, Castranova V, Boegehold MA: Particulate matter exposure impairs systemic microvascular endothelium-dependent dilation. Environ Health Perspect 2004 112(13):1299-1306 
20. Peters A, Fröhlich M, Döring A, Immervoll T, Wichmann HE, Hutchinson WL, Pepys MB, Koenig W: Particulate air pollution is associated with an acute phase response in men; results from the MONICA-Augsburg Study. Eur Heart J 2001, 22(14):1198-204.

21. Verrier RL, Mittleman MA, Stone PH: Air pollution: an insidious and pervasive component of cardiac risk. Circulation 2002, 106:890-892.

22. de Leeuw FAAM, van Rheineck Leyssius HJ: Long-range transport modelling of air pollution episodes. Environ Health Perspect 1989, 79:53-59.

23. Wichmann HE, Mueller W, Allhoff P, Beckmann M, Bocter N, Csicsaky MJ, Jung M, Molik B, Schoeneberg G: Health Effects During a Smog Episode in West Germany in 1985. Environ Health Perspect 1989, 79:89-99.

24. Keil U, Stieber J, Döring A, Chambless L, Härtel U, Filipiak B, Hense HW, Tietze M, Gostomzyk JG: The cardiovascular risk factor profile in the study area Augsburg: Results from the first MONICA survey 1984/85. Acta Med Scand 1988, 728:119-128.

25. Ibald-Mulli A, Stieber J, Wichmann HE, Koenig W, Peters A: Effects of air pollution on blood pressure: a population-based approach. Am J Public Health 2001, 1(4):571-7.

26. Peters A, von Klot S, Heier M, Trentinaglia I, Hörmann A, Wichmann HE, Löwel $\mathrm{H}$ : Exposure to traffic and the onset of myocardial infarction. $N$ Engl J Med 2004, 351(17):1721-1730

27. Bikhazi AB, Saadeh FA, Haddad RE, Nahle ZA, Abou Fares MF, Bitar KM, Birbari AE: Insulin-receptor binding characteristics in perfused SHR and WKY rat hearts. Comp Biochem Physiol C Pharmacol Toxicol Endocrinol 1998 120(1):127-136.

28. Sebkhi A, Zhao L, Lu L, Haley CS, Nunez DJ, Wilkins MR: Genetic determination of cardiac mass in normotensive rats: results from an F344xWKY cross. Hypertension 1999, 33(4):949-953.

29. Kodavanti UP, Schladweiler MC, Ledbetter AD, Ortuno RV, Suffia M, Evansky P, Richards JH, Jaskot RH, Thomas R, Karoly E, Huang YC, Costa DL, Gilmour PS, Pinkerton KE: The spontaneously hypertensive rat: an experimental model of sulfur dioxide-induced airways disease. Toxicol Sci 2006, 94(1):193-205.

30. Mangum JB, Bermudez E, Sar M, Everitt J: Osteopontin expression in particle-induced lung disease. 2004, 30(7):585-598.

31. Kodavanti UP, Schladweiler MC, Ledbetter AD, Watkinson WP, Campen MJ, Winsett DW, Richards JR, Crissman KM, Hatch GE, Costa DL: The spontaneously hypertensive rat as a model of human cardiovascular disease: evidence of exacerbated cardiopulmonary injury and oxidative stress from inhaled emission particulate matter. Toxicol Appl Pharmacol 2000, 164(3):250-63

32. Brook RD, Rajagopalan S, Pope CA, Brook JR, Bhatnagar A, Diez-Roux AV, Holguin F, Hong Y, Luepker RV, Mittleman MA, Peters A, Siscovick D, Smith SC Jr, Whitsel L, Kaufman JD: Particulate Matter Air Pollution and Cardiovascular Disease. An Update to the Scientific Statement From the American Heart Association. Circulation 2010.

33. Nogueira JB: Air pollution and cardiovascular disease. Rev Port Cardiol 2009, 28(6):715-733.

34. Peters A, Schneider A, Greven S, Bellander T, Forastiere F, Ibald-Mulli A, Illig T, Jacquemin B, Katsouyanni K, Koenig W, Lanki T, Pekkanen J, Pershagen G, Picciotto S, Rückerl R, Rosario AS, Stefanadis C, Sunyer J: Air pollution and inflammatory response in myocardial infarction survivors: gene-environment interactions in a high-risk group. Inhal Toxicol 2007, 19:161-175.

35. Nemmar A, Hoet PH, Vermylen J, Nemery B, Hoylaerts MF: Pharmacological stabilization of mast cells abrogates late thrombotic events induced by diesel exhaust particles in hamsters. Circulation 2004, 110(12):1670-1677.

36. Gerlofs-Nijland ME, Boere AJ, Leseman DL, Dormans JA, Sandström T, Salonen RO, van Bree L, Cassee FR: Effects of particulate matter on the pulmonary and vascular system: time course in spontaneously hypertensive rats. Part Fibre Toxicol 2005, 2(1):2..

37. Cyrys J, Pitz M, Heinrich J, Wichmann HE, Peters A: Spatial and temporal variation of particle number concentration in Augsburg, Germany. Science of the Total Environment 2008, 401(1-3):168-175.

38. Pitz M, Birmili W, Schmid O, Peters A, Wichmann HE, Cyrys J: Quality control and quality assurance for particle size distribution measurements at an urban monitoring station in Augsburg, Germany. Journal of Environmental Monitoring 2008, 10(9):1017-1024.

39. Pitz M, Schmid O, Heinrich J, Birmili W, Maguhn J, Zimmermann R, Wichmann HE, Peters A, Cyrys J: Seasonal and diurnal variation of PM2.5 apparent particle density in urban air in Augsburg, Germany Environmental Science and Technology 2008, 42(14):5087-5093.

40. Sklorz M, Schnelle-Kreis J, Liu Y, Orasche J, Zimmermann R: Daytime resolved analysis of polycyclic aromatic hydrocarbons in urban aerosol samples - impact of sources and meteorological conditions. Chemosphere 2007, 67(5):934-943.

41. Sklorz M, Briedé JJ, Schnelle-Kreis J, Liu Y, Cyrys J, de Kok TM Zimmermann R: Concentration of oxygenated polycyclic aromatic hydrocarbons and oxygen free radical formation from urban particulate matter. J Toxicol Environ Health A 2007, 70(21):1866-1869.

42. Schnelle-Kreis J, Sklorz M, Orasche J, Stölzel M, Peters A, Zimmermann R: Semii volatile organic compounds in ambient PM2.5. Seasonal trends and daily resolved source contributions. Environ Sci Technol 2007, 41(11):3821-3828.

43. Schnelle-Kreis J, Küpper U, Sklorz M, Cyrys J, Briedé JJ, Peters A, Zimmermann R: Daily measurement of organic compounds in ambient particulate matter in Augsburg, Germany: new aspects on aerosol sources and aerosol related health effects. Biomarkers 2009, 14(1):39-44.

44. Elder A, Couderc JP, Gelein R, Eberly S, Cox C, Xia X, Zareba W, Hopke P, Watts W, Kittelson D, Frampton M, Utell M, Oberdörster G: Effects of onroad highway aerosol exposures on autonomic responses in aged, spontaneously hypertensive rats. Inhal Toxicol 2007, 19(1):1-12.

45. Upadhyay S, Stoeger T, Harder V, Thomas RF, Schladweiler MC, SemmlerBehnke M, Takenaka S, Karg E, Reitmeir P, Bader M, Stampfl A, Kodavanti UP, Schulz H: Exposure to ultrafine carbon particles at levels below detectable pulmonary inflammation affects cardiovascular performance in spontaneously hypertensive rats. Part Fibre Toxicol 2008, 5:19.

46. Campen MJ, Nolan JP, Schladweiler MC, Kodavanti UP, Costa DL, Watkinson WP: Cardiac and thermoregulatory effects of instilled particulate matter-associated transition metals in healthy and cardiopulmonary-compromised rats. J Toxicol Environ Health A 2002, 65(20):1615-1631.

47. Wichers LB, Nolan JP, Winsett DW, Ledbetter AD, Kodavanti UP, Schladweiler MC, Costa DL, Watkinson WP: Effects of instilled combustionderived particles in spontaneously hypertensive rats. Part II: Pulmonary responses. Inhal Toxicol 2004, 16(6-7):407-419.

48. Geiser M, Rothen-Rutishauser B, Kapp N, Schürch S, Kreyling W, Schulz H, Semmler M, Im Hof V, Heyder J, Gehr P: Ultrafine particles cross cellular membranes by nonphagocytic mechanisms in lungs and in cultured cells. Environ Health Perspect 2005, 113(11):1555-1560.

49. Kreyling WG, Möller W, Semmler-Behnke M, Obersdörster G: Particle Dosimetry: Deposition and clearance from the Respiratory Tract and Translocation Towards Extra-Pulmonary Sites. In Particle Toxicology. Edited by: Donaldson K, Borm P. New York: CRC Press/Taylor 2007:48-69.

50. O'Regan A: The Role of osteopontin in lung disease. Cytokine \& Growth Factor Reviews 2003, 14(6):479-488.

51. Rückerl $R$, Greven $S$, Ljungman $P$, Aalto $P$, Antoniades $C$, Bellander $T$, Berglind N, Chrysohoou C, Forastiere F, Jacquemin B, von Klot S, Koenig W, Küchenhoff H, Lanki T, Pekkanen J, Perucci CA, Schneider A, Sunyer J, Peters A: Air pollution and inflammation (interleukin-6, C-reactive protein, fibrinogen) in myocardial infarction survivors. Environ Health Perspect 2007, 115(7):1072-1080.

52. Lei YC, Chen MC, Chan CC, Wang PY, Lee CT, Cheng TJ: Effects of concentrated ambient particles on airway responsiveness and pulmonary inflammation in pulmonary hypertensive rats. Inhal Toxicol 2004, 16(11-12):785-792.

53. Seaton A, Soutar A, Crawford V, Elton R, McNerlan S, Cherrie J, Watt M, Agius R, Stout R: Particulate air pollution and the blood. Thorax 1999, 54(11):1027-1032.

54. Polichetti G, Cocco S, Spinali A, Trimarco V, Nunziata A: Effects of particulate matter (PM(10), $\mathrm{PM}(2.5)$ and $\mathrm{PM}(1))$ on the cardiovascular system. Toxicology 2009, 261(1-2):1-8.

55. Zhao J, Xie Y, Qian X, Jiang R, Song W: Acute effects of fine particles on cardiovascular system: differences between the spontaneously hypertensive rats and wistar kyoto rats. Toxicol Lett 193(1):50-60.

56. Mills NL, Donaldson K, Hadoke PW, Boon NA, MacNee W, Cassee FR, Sandström T, Blomberg A, Newby DE: Adverse cardiovascular effects of air pollution. Nat Clin Pract Cardiovasc Med 2009, 6(1):36-44. 
57. Ridker PM, Cushman M, Stampfer MJ, Tracy RP, Hennekens CH: Inflammation, aspirin, and the risk of cardiovascular disease in apparently healthy men. N Engl J Med 1997, 336:973-979.

58. Ridker PM: Clinical application of C-reactive protein for cardiovascular disease detection and prevention. Circulation 2003, 107(3):363-369.

59. Driscoll KE, Hassenbein DG, Carter JM, Kunkel SL, Quinlan TR, Mossman BT: TNF alpha and increased chemokine expression in rat lung after particle exposure. Toxicol Lett 1995, 82-83, 483-489.

60. Nemmar A, Nemery B, Hoet PH, Vermylen J, Hoylaerts MF: Pulmonary inflammation and thrombogenicity caused by diesel particles in hamsters: role of histamine. Am J Respir Crit Care Med 2003, 168(11):1366-1372.

61. Kodavanti UP, Schladweiler MC, Ledbetter AD, Hauser R, Christiani DC, McGee J, Richards JR, Costa DL: Temporal association between pulmonary and systemic effects of particulate matter in healthy and cardiovascular compromised rats. J Toxicol Environ Health A 2002, 65(20):1545-1569.

62. Kodavanti UP, Schladweiler MC, Gilmour PS, Wallenborn JG, Mandavilli BS, Ledbetter AD, Christiani DC, Runge MS, Karoly ED, Costa DL, Peddada S, Jaskot R, Richards JH, Thomas R, Madamanchi NR, Nyska A: The role of particulate matter-associated zinc in cardiac injury in rats. Environ Health Perspect 2008, 116(1):13-20.

63. Stoeger T, Reinhard C, Takenaka S, Schroeppel A, Karg E, Ritter B, Heyder J, Schulz H: Instillation of six different ultrafine carbon particles indicates a surface area threshold dose for acute lung inflammation in mice. Environ Health Perspect 2006, 114(3):328-33.

64. Wallenborn JG, Schladweiler MJ, Richards JH, Kodavanti UP: Differential pulmonary and cardiac effects of pulmonary exposure to a panel of particulate matter-associated metals. Toxicol Appl Pharmacol 2009, 241(1):71-80.

65. Bagate K, Meiring JJ, Gerlofs-Nijland ME, Cassee FR, Borm PJ: Signal transduction pathways involved in particulate matter induced relaxation in rat aorta-spontaneous hypertensive versus Wistar Kyoto rats. Toxicol In Vitro 2006, 20(1):52-62.

66. Wedgwood S, Black SM: Role of reactive oxygen species in vascular remodeling associated with pulmonary hypertension. Antioxid Redox Signal 2003, 5(6):759-769.

67. Brodsky SV, Malinowski K, Golightly M, Jesty J, Goligorsky MS: Plasminogen activator inhibitor-1 promotes formation of endothelial microparticles with procoagulant potential. Circulation 2002, 106:2372-2378.

68. Schneiderman J, Sawdey MS, Keeton MR, Bordin GM, Bernstein EF, Dilley RB, Loskutoff DJ: Increased type 1 plasminogen activator inhibitor gene expression in atherosclerotic human arteries. Proc Natl Acad Sci USA 1992, 89(15):6998-7002.

69. Youming $P$, Hong L, Fuyou L, Lin O, Meichu C, Lei G, Fulin P, Yinghong L, Xing C, Jun L: Atherosclerosis is associated with plasminogen activator inhibitor type-1 in chronic haemodialysis patients. Nephrology 2008, 13(7):579-586, (8).

70. Lahm T, Crisostomo PR, Markel TA, Wang M, Lillemoe KD, Meldrum DR: The critical role of vascular endothelial growth factor in pulmonary vascular remodeling after lung injury. Shock 2007, 28(1):4-14.

71. Tuder RM, Flook BE, Voelkel NF: Increased Gene Expression for VEGF and the VEGF Receptors KDRIFlk and Fit in Lungs Exposed to Acute or to Chronic Hypoxia Modulation of Gene Expression by Nitric Oxide. J Clin Invest 1995, 95:1798-1807.

72. Campbell Andrew IM, Yidan Zhao, Reena Sandhu, Duncan J Stewart: CellBased Gene Transfer of Vascular Endothelial Growth Factor Attenuates Monocrotaline-Induced Pulmonary Hypertension. Circulation 2001, 104:2242-2248.

73. Cybulsky MI, liyama K, Li H, Zhu S, Chen M, liyama M, Davis V, GutierrezRamos JC, Connelly PW, Milstone DS: A major role for VCAM-1, but not ICAM-1, in early atherosclerosis. J Clin Invest 2001, 107(10):1255-1262.

74. Davies MJ, Gordon JL, Gearing AJ, Pigott R, Woolf N, Katz D, Kyriakopoulos A: The expression of the adhesion molecules ICAM-1, VCAM-1, PECAM, and E-selectin in human atherosclerosis. J Pathol 1993, 171(3):223-229.

75. Hanyu M, Kume N, Ikeda T, Minami M, Kita T, Komeda M: VCAM-1 expression precedes macrophage infiltration into subendothelium of vein grafts interposed into carotid arteries in hypercholesterolemic rabbits-a potential role in vein graft atherosclerosis. Atherosclerosis 2001, 158(2):313-319.
76. Hunninghake DB: Cardiovascular disease in chronic obstructive pulmonary disease. Proc Am Thorac Soc 2005, 2(1):44-49.

77. Karoly ED, Li Z, Dailey LA, Hyseni X, Huang YC: Up-regulation of tissue factor in human pulmonary artery endothelial cells after ultrafine particle exposure. Environ Health Perspect 2007, 115:535-540.

78. Gilmour PS, Nyska A, Schladweiler MC, MCGee JK, Wallenborn JG, Richards JH, Kodavanti UP: Cardiovascular and blood coagulative effects of pulmonary zinc exposure. J Toxicol Appl Pharmacol 2006, 211:41-52.

79. Poli KA, Tofler GH, Larson MG, Evans JC, Sutherland PA, Lipinska I, Mittleman MA, Muller JE, D'Agostino RB, Wilson PW, Levy D: Association of blood pressure with fibrinolytic potential in the Framingham offspring population. Circulation 2000, 101:264-269.

80. Hong HJ, Chan P, Liu JC, Juan SH, Huang MT, Lin JG, Cheng TH: Angiotensin II induces endothelin-1 gene expression via extracellular signal-regulated kinase pathway in rat aortic smooth muscle cells. Cardiovasc Res 2004, 61(1):159-168.

81. Kanno K, Hirata Y, Tsujino M, Imai T, Shichiri M, Ito H, Marumo F: Upregulation of ETB receptor subtype mRNA by angiotensin II in rat cardiomyocytes. Biochem Biophys Res Commun 1993, 194(3):1282-1287.

82. Gerlofs-Nijland ME, Rummelhard M, Boere AJ, Leseman DL, Duffin R, Schins RP, Borm PJ, Sillanpää M, Salonen RO, Cassee FR: Particle induced toxicity in relation to transition metal and polycyclic aromatic hydrocarbon contents. Environ Sci Technol 2009, 43(13):4729-4736.

83. Donaldson K, Tran L, Jimenez LA, Duffin R, Newby DE, Mills N, Mac-Nee W, Stone V: Combustion-derived nanoparticles: a review of their toxicology following inhalation exposure. Part Fibre Toxicol 2005, 2(10).

84. Happo MS, Salonen RO, Hälinen Al, Jalava PI, Pennanen AS, Dormans JA, Gerlofs-Nijland ME, Cassee FR, Kosma VM, Sillanpää M, Hillamo R, Hirvonen MR: Inflammation and tissue damage in mouse lung by single and repeated dosing of urban air coarse and fine particles collected from six European cities. Inhal Toxicol 2010, 22(5):402-416.

85. Brown RH, Walters DM, Greenberg RS, Mitzner W: A method of endotracheal intubation and pulmonary functional assessment for repeated studies in mice. J Appl Physiol 1999, 87(6):2362-2365.

86. Harder V, Gilmour P, Lentner B, Karg E, Takenaka S, Ziesenis A, Stampfl A, Kodavanti U, Heyder J, Schulz H: Cardiovascular responses in unrestrained WKY rats to inhaled ultrafine carbon particles. Inhal Toxicol 2005, 17(1):29-42.

doi:10.1186/1743-8977-7-27

Cite this article as: Upadhyay et al:: Cardiovascular and inflammatory effects of intratracheally instilled ambient dust from Augsburg, Germany, in spontaneously hypertensive rats (SHRs). Particle and Fibre Toxicology 2010 7:27.

\section{Submit your next manuscript to BioMed Central and take full advantage of:}

- Convenient online submission

- Thorough peer review

- No space constraints or color figure charges

- Immediate publication on acceptance

- Inclusion in PubMed, CAS, Scopus and Google Scholar

- Research which is freely available for redistribution

Submit your manuscript at www.biomedcentral.com/submit
Biomed Central 